\title{
Miško biokuro išteklių potencialo ir gamybos modeliavimas
}

\section{Eugenija Farida Dzenajavičienė,}

Vaclovas Kveselis,

\section{Matas Tamonis}

Lietuvos energetikos institutas,

Regionu energetikos

pletros laboratorija,

Breslaujos g. 3, LT-44403 Kaunas

El.paštas:farida@mail.lei.lt
Energijos gamyba naudojant atsinaujinančius energijos išteklius yra vienas iš Europos Sąungos (ES) energetikos politikos prioritetų. ES siekia mažinti ekonominę priklausomybę nuo iš trečiųjų šalių importuojamo kuro ir neigiamą energetikos poveikị aplinkai mažinant $\mathrm{CO}_{2}$ emisijas. Vienas atsinaujinančių energijos išteklių yra biokuras, kurio naudojimas skatina vietinès ekonomikos augimą ir sukuria darbo vietas. Be to, energijos šaltinių diversifikavimas didina energijos tiekimo patikimumą.

Iki šiol nẻra sukurta patikimų irankių - metodikų ir modelių - tiek atsinaujinančių išteklių potencialo vertinimui ir investicijų planavimui biokuro gamybos sąnaudų pagrindu, tiek ir investicijų planavimui šilumos tiekimo sektoriuje, remiantis darnaus planavimo principais ir diegiant pažangias individualaus ir centralizuoto šilumos tiekimo technologijas.

Autoriu pristatomame tyrime buvo sukurta biokuro gamybos potencialo ir gamybos vertinimo metodika bei atitinkamas modelis. Modeliavimas parodè, kad skiedros gamybą būtų galima padidinti $1 \mathrm{mln} . \mathrm{m}^{3} / \mathrm{metus}$ ir pagaminti dvigubai daugiau biokuro nei gaminama dabar panaudojant 10 \% šiuo metu miške paliekamų kirtimų ir miško tvarkymo atliekų. Straipsnyje parodyta, kad visas potencialas sudarytų apie 4250 tūkst. $\mathrm{m}^{3} /$ metus biokuro. Biokuro gamybos potencialo vertinimo metodika, susiejanti potencialius biomasès išteklius biokuro gamybai konkrečioje savivaldybės teritorijoje su miško kirtimų ir miškotvarkos darbų apimtimis, ir autorių atlikta biokuro gamybos ir transportavimo sąnaudų tyrimo analizė parodè, kad svarbiausi veiksniai, lemiantys biomasès panaudojimą biokuro gamybai, yra biomasès ištraukimo iš miškų atstumas, 1 ha plote susidarančių atliekų tūris ir kuro sąnaudos bei biokuro transportavimo ị katilines atstumas.

Raktažodžiai: biokuras, modeliavimas, planavimas, gamybos sąnaudos

\section{IVADAS}

Vienas iš Europos Sąjungos energetikos politikos prioritetu yra energijos gamyba naudojant atsinaujinančius energijos išteklius, leidžiančius mažinti ekonominę priklausomybę nuo iš trečiųjų šalių importuojamo kuro, ir neigiamą energetikos poveiki aplinkai sumažinant $\mathrm{CO}_{2}$ emisijas. Vienas iš Lietuvai svarbiausių atsinaujinančiu energijos išteklių yra biokuras. Jo naudojimas ne tik pa- deda igyvendinti ES tikslus, bet taip pat skatina ekonomikos augimą ir sukuria naujų darbo vietų bei didina energijos tiekimo patikimumą.

Atsinaujinančiu išteklių energetikos (AIE) įstatymas [1] ippareigoja Lietuvos savivaldybes parengti ir, suderinus su Vyriausybe ar jos igaliota institucija, tvirtinti bei igyvendinti atsinaujinančiųjų išteklių energijos naudojimo plètros veiksmų planus, kuriuose centralizuotas šilumos tiekimas (CŠT) vaidina svarbų vaidmenị ir leidžia panaudoti 
atliekinę šilumą bei atsinaujinančius energijos išteklius, tarp jų ir biokurą.

Iki šiol nẻra sukurta patikimų irankių - metodikų ir modelių - atsinaujinančių energijos išteklių potencialo vertinimui ir investicijų planavimui biokuro gamybos sąnaudų pagrindu. Straipsnyje pateikta originali miškų biomasės potencialo vertinimo metodika ir imitacinis modelis, paremtas miškų ūkio statistikos duomenimis, skirtas galimų biokuro gamybos apimčių ịvertinimui atsižvelgiant i esamo potencialo panaudojimo laipsni.

Biokuro gavybos, gamybos ir vartojimo mokslinių tyrimų bei praktikos raidos Lietuvoje vertinimas

Publikacijų biokuro gamybos ir naudojimo tematika analizė rodo, kad šios problemos Lietuvoje išsamiau pradètos tyrinèti tik po $1990 \mathrm{~m}$., o pagrindiniai tyrimai buvo skirti medienos kuro potencialo nustatymui ir jo panaudojimo galimybiu įvertinimui.

Pirmieji tyrimai nustatė skirtingas kirtimų atliekų apimtis dèl taikytų nesuderintų normatyvų, nevienodos kirtimo atliekų struktūros bei informacijos trūkumo. Prie jų derètų priskirti Lietuvos energetikos instituto (LEI) parengtą Lietuvos ataskaitą Europos atsinaujinančios energetikos studijai [2] ir Lahmayer International ir Cowi Consult ekspertų atliktą Lietuvos nuosavų išteklių, tinkamų energijai gaminti, apžvalgą [3]. Čia malkų ir miškininkystės atliekų energinis potencialas, nustatytas 1226 tūkst. ha valstybinių miškų plotui artimuoju laikotarpiu (1990-1995), buvo ịvertintas 3,8 PJ (0,857 TWh), o ilgalaikejje perspektyvoje - iki 21,58 PJ (6 TWh) per metus [2]. Kadangi faktinis visas Lietuvos miškų plotas buvo apie 1,75 karto didesnis, remiantis šiais duomenimis, 1990-1995 m. metinis malkų gamybos ir miškininkystès atliekų energinis potencialas turèjo būti vertinamas 1,5 TWh, o ilgalaikèje perspektyvoje padidèti iki 10,5 TWh. Lahmayer studijoje [3] buvo ivertinta, kad $1993 \mathrm{~m}$. sunaudota 1,8 TWh medienos kuro, 0 prognozuojamas potencialas - 15,7 TWh/metus. Šių dviejų studijų skirtingų rezultatų priežastimi galëjo būti skirtingi įvesties duomenys (miškų plotas, biokuro šilumingumas, medienos tankis ir t. t.).

ES PHARE programos finansuotoje studijoje [4] visų atsinaujinančiujų energijos išteklių vartojimas $1997 \mathrm{~m}$. ivertintas 3,8 TWh/metus ir prognozuojamas vartojimas iki $15 \mathrm{TWh} /$ metus, iš jų kietojo biokuro - $1 \mathrm{TWh} /$ metus. Apie $0,45 \mathrm{TWh} /$ metus energijos galèjo būti gaminama naudojant medieną. Palyginus su [2], vartojimas sudare apie $52 \%$ pagal kirtimų apimtis apskaičiuoto potencialo.
Danish Energy Management A/S parengtos studijos [5] duomenimis, medienos kuro potencialas sudaro 9,8 TWh/ metus, t. y. artimas techniniam potencialui, apskaičiuotam pagal kirtimų apimtis [2]. Kiek vèliau, 2003 m., LEI-EREC parengta Europos Komisijos Altener programos finansuota studija apie atsinaujinančios energetikos politiką Lietuvoje [6], kurioje medienos kuro potencialas 2020 m., kaip ir Danijos ekspertų studijoje, ivvertintas 9,8 TWh/metus.

Pirmųjų tyrimų išskirtinumas, kad juos pradèjo energetikai, ieškodami naujų vietinių energijos išteklių. 1999$2000 \mathrm{~m}$. vykdytame bendrame Lietuvos-Švedijos projekte „Medienos panaudojimo kurui plètra Lietuvoje“ jau dalyvavo ir miškininkų atstovai - Rokiškio uredija. Buvo nustatyta, kad bendras medienos atliekų, tinkamų energijos gamybai, tūris yra 2,7 mln. $\mathrm{m}^{3}$ (4,17 TWh/metus), iš kurio apie $0,8 \mathrm{mln} \cdot \mathrm{m}^{3}$ (1,67 TWh/metus) yra kirtimu atliekos, apie $0,8 \mathrm{mln} \cdot \mathrm{m}^{3}$ (1,67 TWh/metus) - medienos pramonès pjuvenos ir drožlès. Likusi dalis, apie $1,1 \mathrm{mln} . \mathrm{m}^{3}$ (2,29 TWh/ metus), - malkos [7]. Potencialiais kuro šaltiniais laikomos tiek malkos, tiek likvidinès medienos gamybos atliekos. 1990-2009 m. Lietuvos miškuose per metus buvo iškertama nuo 3 iki 5,7-6,5, 1990-2007 m. - 6,2-6,5 mln. $\mathrm{m}^{3}$ medienos. Iš ju $2009 \mathrm{~m}$. buvo pagaminta ir parduota $0,623 \mathrm{mln} . \mathrm{m}^{3}$ (1,3 TWh), o 2007 m. - 0,442 mln. $\mathrm{m}^{3}$ (0,922 TWh) malku.

Biokuro - kapotinès skiedros - pardavimu kaita pateikta 1 lentelèje [8]. Šie skaičiai rodo akivaizdžius medienos kuro gamybos pokyčius 2005-2011 m.

Rengiant Nacionalinę biomasès ir biokuro gamybos ir naudojimo technologiju platformos galimybiu studija malkine mediena buvo laikoma ta stiebu dalis, kuri netinka perdirbimui ir sudaro apie $15 \%$ iškertamos miškų medienos tūrio - apie 0,9-1,0 mln. $\mathrm{m}^{3}$ per metus [9]. Kauno mišku ir aplinkos inžinerijos kolegijos specialistai yra sukūrę miško kirtimo atliekų kiekio įvertinimo metodiką ir nustatę, kad kasmet visose Lietuvos urédijose bendras kirtimo atliekų tūris, kurị galima panaudoti nedarant žalos gamtai, gali siekti iki $0,78 \mathrm{mln} . \mathrm{m}^{3}[10,11]$. Yra duomenų, kad medienos kuro gamybos apimtys galèjo būti dar didesnès. Anot Lietuvos biomasès energetikos asociacijos LITBIOMA, tokio kuro buvo sunaudojama gerokai daugiau valstybiniuose miškuose pagaminama apie $1,23 \mathrm{mln} . \mathrm{m}^{3}$ malkų, o privačiuose miškuose $-0,99 \mathrm{mln}$. $\mathrm{m}^{3}$, t. $\mathrm{y}$. iš viso apie $2,22 \mathrm{mln} . \mathrm{m}^{3}$ [12].

Aleksandro Stulginskio universiteto vertinimu, kasmet susidaro apie $2,5 \mathrm{mln} . \mathrm{m}^{3}$ kirtimo atliekų, tačiau realiai biokurui galima panaudoti ne daugiau kaip $1 \mathrm{mln} . \mathrm{m}^{3}$ [13]. Medienos kuro gamybos ir vartojimo rezultatų skir-

1 lentelè. Miško kirtimo atliekų pardavimų kaita 2005-2011 metais

\begin{tabular}{c|c|c|c|c|c|c|c}
\hline Pardavimų metai & $\mathbf{2 0 0 5}$ & $\mathbf{2 0 0 6}$ & $\mathbf{2 0 0 7}$ & $\mathbf{2 0 0 8}$ & $\mathbf{2 0 0 9}$ & $\mathbf{2 0 1 0}$ & $\mathbf{2 0 1 1}$ \\
\hline Pardavimų tūriai 1 $000 \mathrm{~m}^{3}$ & 64,5 & 75,6 & 56,5 & 71,6 & 76,9 & 74,8 \\
\hline Energetinè vertè GWh & 133,6 & 156,6 & 117,1 & 148,3 & 159,3 & 155,0 \\
\hline
\end{tabular}


2 lentelè. Miško kirtimų ir susidarančių kirtimo atliekų kiekio prognozė

\begin{tabular}{|c|c|c|c|}
\hline Laikotarpis & $\begin{array}{l}\text { Kirtimų apimtis } \\
\mathrm{mln} . \mathrm{m}^{3} / \mathrm{metus}\end{array}$ & $\begin{array}{l}\text { Susidarančių kirtimo atliekų kiekis } \\
\text { mln. } \mathrm{m}^{3} / \mathrm{metus}\end{array}$ & $\begin{array}{l}\text { Atliekų energinè vertè } \\
\text { TWh/metus }\end{array}$ \\
\hline 2001-2010 & 6,3 & 0,975 & 3,03 \\
\hline $2011-2020$ & 7,5 & 1,125 & 2,35 \\
\hline $2021-2030$ & 8,3 & 1,245 & 2,6 \\
\hline
\end{tabular}

tumus lemia naudotos nevienodos metodikos, tyrejų disponuojama informacija bei medienos apdorojimo ir perdirbimo technologijų tobulejjimas.

Medienos kuro sunaudojimas ėmé sparčiai augti, kai mediena pradèta kūrenti centralizuoto šilumos tiekimo (CŠT) katilinėse. Padètas deginti kokybiškai naujo tipo biokuras - medienos kapotine skiedra, gauta susmulkinus medienos kirtimo arba perdirbimo atliekas.

Numatomi iškertamos medienos kiekiai $[9,14]$, kurie daugiausia lems kirtimo atliekų apimtis (2 lentelè).

Yra ir kitokių prognozių. Lietuvos agrarinių ir miškų mokslu centro Lietuvos mišku instituto mokslininkai A. Kuliešis ir E. Petrauskas atliko 2001-2030 m. mišku medienos išteklių prognozę, pagal kurią $2025 \mathrm{~m}$. kirtimu apimtys sudarys $8,94 \mathrm{mln} . \mathrm{m}^{3}$, o malkinès medienos gamybos apimtys vertinamos 2,68 mln. $\mathrm{m}^{3}$ (5,59 TWh) [15]. Didesniają šiu atlieku dali, apie 1,63 mln. $\mathrm{m}^{3}$ (5,59 TWh), sudarys medienos pramonès atliekos. Kirtimo atliekos sieks apie 1,08 mln. $\mathrm{m}^{3}$ (2,25 TWh) [16]. Kiti šio instituto specialistai, atlike išsamią visos medienos panaudojimo kurui analizę [17], nustatė, kad Lietuvoje gyventojai kasmet sukūrena po 2,2-2,5 mln. $\mathrm{m}^{3}$ malkų ir medienos pramonès atlieku, t. y. energinės sąnaudos sudaro apie 5,2 TWh per metus [18]. Tai rodo, kad dalis gyventojų neperka malkų iš miškininkystès ūkio įmonių.
Remiantis Lietuvos energetikos statistikos duomenimis [19], pastebimos biokuro gamybos ir vartojimo kaitos tendencijas pateiktos 1 pav.

Parodytas biokuro vartojimas (1 pav.) namų ūkiuose yra viso galutinio vartojimo dalis. Statistinis galutinis vartojimas 1990-1991 m. buvo mažesnis už vartojimą vien tik namų ūkiuose ir tik nuo 1992 m. pradėjo jị viršyti. Biokuro naudojimas augo dèl nedidelès kainos, nesudètingos ir santykinai nebrangios deginimo technologijos, mažesnio teršalų kiekio išmetamuose degimo produktuose. Tai pagrindiniai veiksniai, lèmę pakankamai spartų biokuro gamybos augimą 1993-2011 m. Akivaizdus galutinio vartojimo padidèjimas remiasi $2009 \mathrm{~m}$. tyrimo duomenimis [17] apie energijos suvartojimą namų ūkiuose ir gali būti siejamas su naftos bei gamtinių dujų kainų šuoliu.

Pateikti duomenys rodo, kad per pastaruosius 20 metu biokuro gamyba išaugo nuo 3,3 iki beveik 10,9 TWh/metus. Individualiems namams šildyti miškininkystès ūkyje pagaminama apie 2,3-2,7 TWh/metus malkinès medienos. Dar apie 5,59 TWh/metus biokuro pagamina medienos apdirbimo pramonè. Tai maždaug atitinka parodyta medienos kuro gamybos lygi 2004-2007 m. Vadinasi, i 1 pav. statistikos duomenis įtraukta tik dalis sunkiai apskaitomos gyventojų malkų saviruošos.

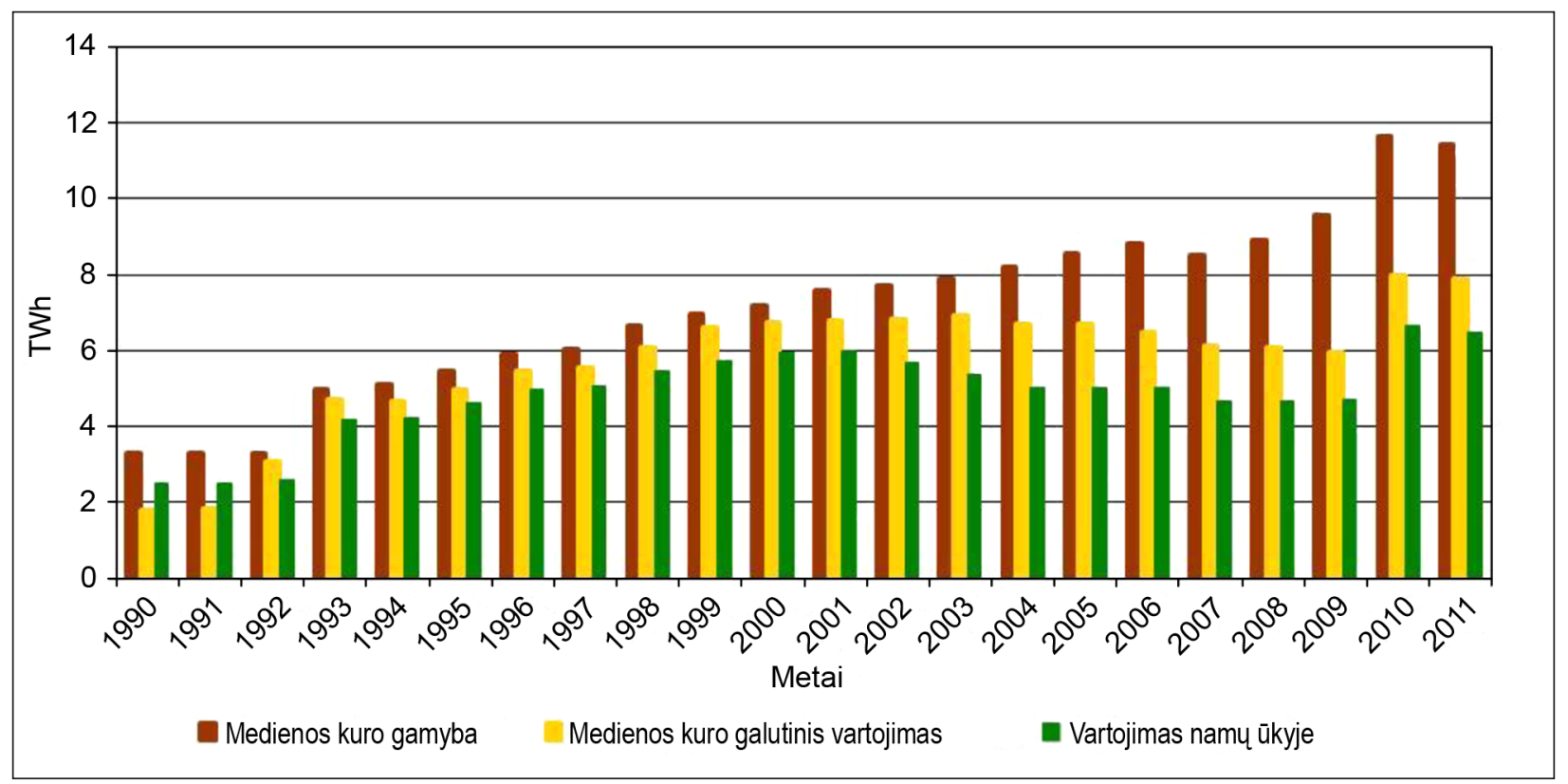

1 pav. Biokuro vartojimas energijos gamybai TWh 
Biokuro gamybos procesų modeliavimas

Biokuro (medienos kapotinés skiedros) gamybos žaliava yra medienos apdorojimo atliekos, miškai, krūmai bei tam tikslui auginamos medžiu plantacijos. Bendruoju atveju technologinis procesas apima:

a) medynų ugdymą;

b) kirtavietėse susidariusių atliekų surinkimą ir ištraukimą iki smulkinimo aikštelių;

c) skiedros gamybą;

d) skiedros transportavimą $\mathfrak{i}$ tarpinius sandèlius ir pateikimą galutiniam vartotojui.

Pirmasis procesas yra aktualus tuomet, kai mediena auginama specialiose plantacijose. Medžių kirtimas (įskaitant dalinį, ekonomiškai pateisinamą kirtimo atliekų surinkimą) yra miškininkystès ūkio prerogatyva. Savivaldybių atsakomybe - biokuro poreikių planavimas bei parama formuojant jo gavybai reikalingą infrastruktūrą. Tam tikslui reikalingą informaciją savivaldybės galètų gauti pasitelkę matematinio modeliavimo rezultatus.

Biokuro gamybos matematiniam modeliui sudaryti šalies ar atskiros savivaldybès lygiu būtina ši informacija: duomenys apie miškų ar jų augimui tinkamos žemės plotus, jų derlingumą, numatomas kirtimų apimtis, kelius ir kitas reikšmingas charakteristikas, o taip pat medienos kirtimo atliekų, tinkamų kuro gamybai, kiekiai, tenkinantys materialinio balanso lygtị:

$$
S G Z \leq K R V(\tau) \cdot \eta(\tau)
$$

čia $S G Z(\tau)$ - skiedros gamybos žaliavų kiekiai laikotarpiu $\tau$ mln. $\mathrm{m}^{3} ; K R V(\tau)$ - metiniai medienos kirtimų kiekiai $\mathrm{mln} . \mathrm{m}^{3} ; \eta(\tau)$ - nukirstos medienos panaudojimo energetinèms reikmèms koeficientas.

Medienos skiedros kiekio energijos poreikiu tenkinimui lygtis:

$$
\sum_{e} S G Z_{e}(\tau) \cdot \eta_{e}(\tau) \leq \sum_{e} E P_{e}(\tau)
$$

čia $S G Z_{e}(\tau)$ - skiedros gamybos žaliavų kiekiai, panaudojami $e$-rūšies energijos gamybai; $\eta_{e}(\tau)$ - medienos skiedros transformavimo ị $e$-rūšies energiją koeficientas; $E P_{e}(\tau)-e$-rūšies energijos poreikiai.

Potencialiu medienos ištekliu kuro gavybai vertinimas. Lietuvos miškų plotas 1990-2010 m. didèjo. Dažniausiai miškų plotas pateikiamas procentais nuo bendro Lietuvos ploto (65,2 tūkst. $\mathrm{km}^{2}$, arba 6,52 mln. ha). Miškų ploto prognozavimui matematiniame modelyje naudojama tiesinès regresijos lygtis:

$$
\begin{aligned}
& M P L(\tau)=0,0112 \text { metai }-20,373 \\
& \tau=\text { metai - 1990; }
\end{aligned}
$$

čia $M P L$ - miškų plotas mln. ha.
Informacijos apie Lietuvos miškuose esančius medienos kiekius iki 2005 m. praktiškai nebuvo ir tik po 2005 m., kai buvo atliktas Pasaulinis miško išteklių ịvertinimas (Global Forest Resources Assessment), atsirado galimybès nustatyti potencialių miško atliekų, naudotinų biokuro gavybai, kieki [20]. Jị atliko Jungtinių Tautų maisto ir žemès ūkio organizacija (FAO). Čia visa miškų biomase buvo suskirstyta i žemès paviršiuje esančią biomasę, po žeme esančią biomasę ir sausuolių biomasę. Kiekviena biomasès kategorija buvo nustatyta naudojantis baziniais kamieninès medienos tankiais pagal medžių rūšis. Gautos gyvų šakų bei šakų, tinkamų kurui, tūrio priklausomybès nuo ji sąlygojančiu parametrų - medžių skersmens, aukštingumo klasès, amžiaus, dirvožemio derlingumo ir drègnumo.

Toks modelis, suderintas su integruoto valstybinio miškų kadastro informacine sistema, leidžia apskaičiuoti bendrą biomasès kiekị Lietuvos regionuose. Nustatytas bendras mišku biomasès kiekis šalyje yra didesnis nei $200 \mathrm{mln}$. $\mathrm{t}$ (ivertinant tik žemès paviršiuje esančią biomasę). Visa biomasė (antžeminè, požeminè ir sausuolių) sudaro apie 275 mln. t.

Mišku kirtimo apimčiu ir susidarančiu atlieku modelis. Turimi statistiniai kirtimų apimčiu duomenys nuo $1990 \mathrm{~m}$. Kiek sudètingiau ịvertinti kirtimu $(K R V(\tau))$ struktūrą dèl pakitusios kirtimu tipu klasifikacijos. Atsižvelgiant ì labai besiskiriančias kirtimo atlieku ištraukimo iš miško sąnaudas, šiame darbe apsiribota 4 kirtaviečiu tipais: plynais, tarpiniais ir ugdomaisiais kirtimais, pastaruosius skaidant ị dvi dalis (jaunuolynuose, kuriụ amžius mažesnis arba didesnis nei 10 metų). Tuomet kirtimų atliekų materialinis balansas yra:

$$
\frac{P L K(\tau)}{K R V(\tau)}+\frac{\operatorname{TRK}(\tau)}{K R V(\tau)}+\frac{J A T 10(\tau)}{K R V(\tau)}+\frac{J A T 20(\tau)}{K R V(\tau)}=1 ;
$$

čia $K R V$ - kirtimų kiekiai mln. $\mathrm{m}^{3} ;$ PLK - plynų kirtimų atliekos mln. $\mathrm{m}^{3}$; TRK - tarpinių kirtimų atliekos mln. $\mathrm{m}^{3}$; JAT10 - jaunuolynų iki 10 metų amžiaus kirtimo atliekos mln. $\mathrm{m}^{3}$; JAT20 - jaunuolynų per 10 metų amžiaus kirtimo atliekos mln. $\mathrm{m}^{3} ; \mathrm{t}$ - laikotarpis metais. Panaudoję santrumpas (4) lygtyje esantiems nariams, turime:

$$
\sum_{i} a_{i}=a_{1}(\tau)+a_{2}(\tau)+a_{3}(\tau)+a_{4}(\tau)=1 .
$$

Miškuose iškertama biomase susideda iš likvidinès ir nelikvidinès medienos, tačiau jos panaudojimo biokuro gamybai vertinimams tokio suskirstymo nepakanka. Likvidinè mediena yra žaliava medienos apdirbimo pramonei, kurui (malkoms) bei kitoms reikmèms. Vystantis technologijoms, malkinè mediena tapo žaliava popieriaus pramonei (popiermalkès), baldų pramonei (medienos drožlių plokštès), aukštesnès kokybès kuro (granulių, briketų) gamybai. Kadangi tam tikra dalis likvidinès medienos (malkos) visada buvo ir tebenaudojama kurui, me- 
dienos naudojimo energetikai plètra turètų būti siejama su nelikvidinès medienos panaudojimu. Tradiciškai miškų kirtimo veikla apibūdinama tik naudingai panaudojamos (likvidžios) medienos rodikliais pamirštant miškuose paliktas atliekas. Neretai pateisinamas kuo didesnio atliekų kiekio palikimas miškuose, motyvuojant miškų dirvožemio kokybès gerinimu, valksmų stiprinimu ar bioịvairovés išsaugojimu. Iš nederlingų miškų kirtimo išvežti atliekas draudžia Pagrindinès miško kirtimo taisyklès. Be to, visų atliekų surinkimas ir panaudojimas biokurui nepateisintų išlaidų. Atliekų susidarymą siejant su kirtimų apimtimis kirtimų balanso lygti galima užrašyti taip:

$$
K R V(\tau)=K R_{A P S}(\tau)+P_{P O T}(\tau)
$$

čia $K R V$ - medienos kirtimų apimtys mln. $\mathrm{m}^{3} ; K R_{A P S}-$ apskaitomos medienos kirtimų apimtys mln. $\mathrm{m}^{3} ; K R_{P O T}-$ potencialios kirtimų atliekų apimtys mln. $\mathrm{m}^{3} ; \tau$ - laikotarpis metais.

Kadangi iškertamos medienos apskaita tvarkoma tik likvidžiai medienai, savaime suprantama, kad likusi nelikvidinès medienos dalis gali būti ịvertinta tik teoriškai, remiantis esamais tyrimais. Taigi, potenciali miško medienos dalis, kurią būtų galima panaudoti energetikos reikmèms:

$$
d(\tau)=\frac{K R_{P O T}(\tau)}{K R V(\tau)} .
$$

Nors Lietuvoje kirtimo atliekų kiekiai vertinami periodiškai, yra susiformavusi nuomoné [21], kad ịvairių autorių skirtingu laiku vykdyti tyrimai yra nepalyginami. Išsamesnè analizè rodo, kad trijų autorių $[15,22,23]$ skirtingu laiku atliktų tyrimų rezultatai skiriasi tik $\pm 3 \%$ (3 lentelè).

Naujesni tyrimų rezultatai [24] rodo esminius kirtimo atliekų pokyčius. Kadangi nẻra duomenų, kad 20052012 m. iš kirtimų būtų panaudoti beveik visi kelmai ir lapai, tai šie rezultatai, cituojant L. Sadauskienę ir kt. [21], negali būti lyginami su ankstesnių tyrimų rezultatais. Tačiau šie tyrimai įdomūs tuo, kad net pakoregavus kelmų ir lapų sandus, jie aiškiai parodo miškuose paliekamų atliekų mažèjimo tendencijas. Nesant kitų duomenų tenka daryti išankstinę prielaidą, kad iki $2020 \mathrm{~m}$. miške paliekamų atliekų dalis galètų būti sumažinta nuo dabartinių 55 iki $40 \%$ (2 pav.).

Esant tokioms prielaidoms, miške paliekamų atliekų kiekio dinamika galètų būti aprašoma lygtimi:

$$
d_{1}(\tau)=11,905-0,0057 \cdot(1988+\tau)
$$

čia $d_{1}$ - viršūnès, šakos, smulkūs stiebai, atraižos mln. $\mathrm{m}^{3}$.

Priimant tokią hipotezę, tektų peržiūrèti praejjusio laikotarpio duomenis. Kita vertus, nèra argumentų paneigti teiginiui, kad iki 2004-2009 m. miške paliekamų atlieku santykinė dalis išliko artima vidutinei buvusiu tyrimu reikšmei (1 lentelè). Toks raidos scenarijus nelikvidinei medienai galètų būti aprašomas:

$$
d_{2}(\tau)=\left\{\begin{array}{l}
0,54, \text { kai } \tau \leq \tau_{k r}, \\
0,54-\alpha \cdot\left(\tau-\tau_{k r}\right), \text { kai } \tau>\tau_{k r}
\end{array} ;\right.
$$

čia $d_{2}$ - nelikvidiné mediena mln. $\mathrm{m}^{3} ; \tau_{k r}-2005 \mathrm{~m}$. (paskutinių atliktų tyrimų metai); $a$ - pasirinktas miške likusių atliekų, panaudotinu skiedros gamybai, regresijos koeficientas - 0,005; 0,01 arba 0,015.

Abi išraiškos galètų būti rekomenduojamos dabartinès būklès vertinimui bei prognostiniams skaičiavimams, kol nebus išsamesnių tyrimų. Antroji lygtis būtų patogesnè, nes ị medienos kirtimų balansines lygtis leistų ịtraukti sandą, apibūdinantị atliekų panaudojimo skiedros gamybai augimą, pasitelkus a parametrą.

Scenarijus pagal (8) lygti yra gana artimas scenarijui

\begin{tabular}{|c|c|c|c|c|c|}
\hline $\begin{array}{l}\text { Kirtimų struktūra tenkinant sąlygą: } \\
\qquad \sum_{i} d_{i}+\sum_{i} b_{i}=1\end{array}$ & $\begin{array}{l}\text { Kenstavičius [22], } \\
1989\end{array}$ & $\begin{array}{l}\text { Grigaliūnas } \\
\text { [23], } 1997\end{array}$ & $\begin{array}{c}\text { Kuliešis } \\
\text { [15], } \\
1999\end{array}$ & $\begin{array}{l}\text { Rutkauskas } \\
{[24], 2005}\end{array}$ & $\begin{array}{l}\text { Matematiniam } \\
\text { modeliui priimtos } \\
\text { vidutinès } \\
\text { reikšmès }\end{array}$ \\
\hline Potencialių medienos atliekų balansas $d(\tau)$ & 0,568 & 0,532 & 0,555 & 0,29 & 0,54 \\
\hline Viršūnès, smulkūs stiebai, atraižos $d_{1}(\tau)$ & 0,195 & 0,228 & 0,3 & 0,06 & 0,22 \\
\hline Nelikvidinès šakos $d_{2}(\tau)$ & 0,159 & $0,207^{*}$ & 0,077 & 0,13 & 0,1 \\
\hline Kelmai ir šaknys $d_{3}(\tau)$ & 0,084 & 0,15 & 0,179 & 0,01 & 0,15 \\
\hline Spygliai ir lapai $d_{4}(\tau)$ & 0,065 & - & 0,021 & - & 0,04 \\
\hline Medienos žievè $d_{5}(\tau)$ & 0,065 & - & 0 & 0,1 & 0,03 \\
\hline Draudžiamų naudoti potencialių atliekų dalis & 0,22 & 0,18 & 0,37 & 0,2 & \\
\hline Likvidinè stiebų mediena $b_{1}(\tau)+b_{2}(\tau)$ & 0,432 & 0,468 & 0,537 & 0,71 & 0,46 \\
\hline Padarinè mediena $b_{1}(\tau)$ & 0,232 & 0,228 & 0,36 & & 0,29 \\
\hline Malkinė mediena $b_{2}(\tau)$ & 0,2 & 0,17 & 0,177 & & 0,17 \\
\hline $\begin{array}{l}\text { Medienos biomasės kirtimų santykis su } \\
\text { apskaitomais likvidiniais kirtimais }\end{array}$ & 2,31 & 2,14 & 1,86 & 1,41 & 2,17 \\
\hline
\end{tabular}
pagal (9) lygti, o kiti scenarijai atitiktų kur kas spartesni kirtimo atliekų panaudojimą.

3 lentelè. Miškų kirtimų struktūrinių tyrimų rezultatų suvestinè $\mathrm{mln} . \mathrm{m}^{3}$ 
2 pav. Potencialių medienos atlieku, kurios paliekamos miške, o dar galètų būti panaudotos kuro gamybai, retrospektyva ir prognozės: $d$ - perspektyvinè raida ir $d v$ - vidutinè reikšmé pagal (7) lygti

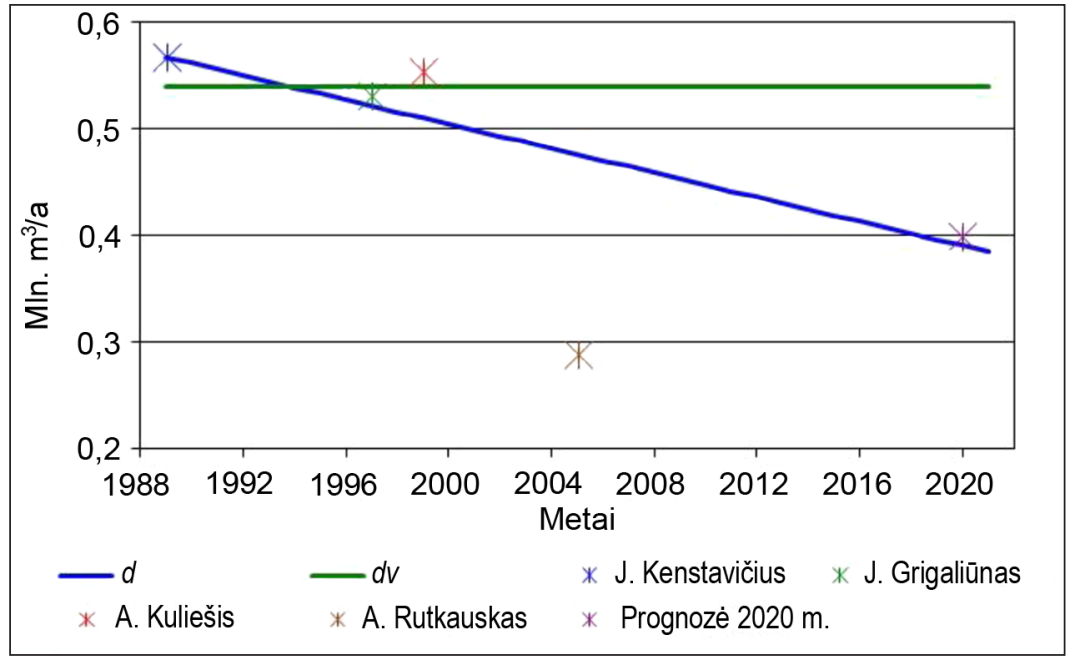

Stabilesni yra padarinès medienos tyrimų duomenys, nors nepavyko rasti aiškiai apibrěžto skirtumo tarp malkinès ir padarinès medienos. Malkine [25] mediena laikoma ta dalis stiebų, kuri netinka perdirbimui (puvinys, kreivumas, kitos ydos). Orientaciniais vertinimais, malkine mediena sudaro apie $15 \%$ iškertamos medienos tūrio.

Kadangi nèra duomenų, kuri malkinès medienos dalis ar iš miško ištraukiamu atlieku kiekis yra panaudojamas skiedros gamybai, priimame hipotetini skiedros gamybos prieaugi laikotarpiui nuo $\tau_{k r}=2005$ iki $2020 \mathrm{~m}$., kuris galètų būti pasiektas vien miške paliekamu potencialiu atlieku mažinimo sąskaita nedidinant miško kirtimų ir malkinès medienos gamybos apimčių. Tokiu atveju malkinès medienos apimtys nustatomos:

$$
b_{2}(\tau)=\left\{\begin{array}{l}
1-b_{1}(\tau)-d_{1}(\tau) \text { arba } 1-b_{1}(\tau)-d_{2}(\tau), \text { kai } \tau \leq \tau_{k r}, \\
b_{2}\left(\tau_{k r}\right), \text { kai } \tau>\tau_{k r} .
\end{array}\right.
$$

I prognozuojamą miško medienos santykinių kirtimų balansą ittraukiant hipotetinį atliekų panaudojimo didinimą skiedros gamybai $S G Z(\tau)$, galime užrašyti:

$$
b_{1}(\tau)=b_{2}(\tau)+d_{1}(\tau)=1
$$

Tuomet santykinis medienos balansas, paprastai sudaromas likvidinès medienos atžvilgiu, panaudojus santrumpas:

$$
\begin{aligned}
& k(\tau)=\frac{\operatorname{LMD}(\tau)}{K R V(\tau)}, \\
& c(\tau)=\frac{S G Z(\tau)}{K R V(\tau)},
\end{aligned}
$$

atrodys taip:

$$
b_{1}(\tau) \cdot k(\tau)+b_{2}(\tau) \cdot k(\tau)+c(\tau)=1
$$

Iš (20) lygties matyti, kad skiedros gamybos didinimui panaudojamų atliekų dalis būtų:

$$
c(\tau)=1-k(\tau) \cdot\left(b_{1}(\tau)+b_{2}(\tau)\right)
$$

Ivertinant skiedros gamybos prieaugiui panaudojamų atlieku dali tiesine priklausomybe nuo laiko parametrine lygtimi:

$$
c(\tau)=\left\{\begin{array}{l}
\alpha \cdot\left(\tau-\tau_{k r}\right), \text { kai } \tau>\tau_{k r}, \\
0, \text { kai } \tau<\tau_{k r} ;
\end{array}\right.
$$

galime rasti visų medienos biomasès kirtimų santykị su apskaitomais likvidiniais kirtimais esant ịvairioms a parametro reikšmėms:

$$
k(\tau)=\frac{1-c(\tau)}{b_{1}(\tau)+b_{2}(\tau)} .
$$

Potencialių medienos atliekų struktūrinių tyrimų duomenys, perskaičiuoti $1 \mathrm{~m}^{3} /$ metus kirtimų apimčiai, pateikti 3 lentelèje, suskirstyti net it 5 sandus:

1) viršūnes, smulkius stiebus, šakas ir t. t.;

2) nelikvidines šakas;

3) kelmus ir šaknis;

4) spyglius ir lapus;

5) padarinès medienos žievę.

Šiuos potencialių atliekų sandus galima ịvertinti balansine lygtimi:

$$
d(\tau)=d_{1}(\tau)+d_{2}(\tau)+d_{3}(\tau)+d_{4}(\tau)+d_{5}(\tau) .
$$

Esančių tyrimų duomenų nepakanka, kad būtų galima išsamiau nagrinèti nelikvidinių atliekų struktūrą. Orientaciniam vertinimui galima priimti, kad viršūnès, smulkūs stiebai, atraižos sudaro apie 34,3\% miško kirtimų atliekų, nelikvidinès šakos - $28 \%$, kelmai - 14,9\%, spygliai ir lapai - 1,4 \% bei 11,4 \% - padarinès medienos žievè. Tokios atliekos gali būti vertinamos kaip biokuro energetiniams tikslams rezervas, jeigu tokių atliekų paèmimas iš miško pasirodytų ekonomiškai patrauklus. 
Energetikos sektoriuje naudojamo biokuro vartojimo modeliavimas

Biokuro gamybos iš miško kirtimo atliekų potencialo ivertinimas. Modelis atkuria miškų plotus ir struktūrą, pateikiamą procentais nuo bendro Lietuvos ploto $(65,2$ tūkst. $\mathrm{km}^{2}$, arba 6,52 mln. ha) [8]. Biokuro ruošai svarbu turèti duomenis apie kirtaviečių pasiskirstymą pagal jų tipą. Remiantis ịvairiais literatūros šaltiniais $[21 \div 24]$ buvo priimta: plyniems kirtimams $a_{1}(\tau)=0,567$, tarpiniams $a_{2}(\tau)=0,343$, jaunuolynams, kurių amžius daugiau nei 10 metų $a_{3}(\tau)=0,08$ ir jaunesniems $a_{4}(\tau)=0,008$. Nesant duomenų apie šių koeficientų kaitą buvo daroma prielaida, kad jie išlieka pastovūs per visą laikotarpi. Esant šioms prielaidoms sumodeliuota nelikvidinès medienos kirtimo apimčių struktūra nagrinèjamam laikotarpiui pa- rodyta 3 pav. Išaugusias kirtimų apimtis 2007 m. lèmė ne tik padarinès bei technologinès medienos paklausa, bet ir škvalų bei uraganinių vėjų neprognozuojamos miškų išvartos. Stichinès nelaimés galèjo turèti ịtakos malkinès gamybos apimtims, bet tai nereiškia, kad dèl to praejusiame dešimtmetyje iš esmès keitèsi daugiau sąnaudų reikalaujantis medienos atliekų panaudojimas.

Suskirsčius potencialių medienos atliekų perskaičiuotus duomenis $d$ iš (18) lygties, kaip parodyta 3 lentelèje, $j 5$ sandus: (1) $d_{1}$ - viršūnes, smulkius stiebus, šakas ir pan.; 2) $d_{2}$ - nelikvidines šakas; 3 ) $d_{3}$ - kelmus ir šaknis; 4) $d_{4}$ - spyglius ir lapus; 5) $d_{5}$ - padarinès medienos žievę, galima sumodeliuoti potencialių miško atliekų dinamiką. Skaičiavimai rodo, kad parametras a gali būti didinamas geresnio smulkių stiebų, šakų ar kelmų panaudojimo sąskaita (4 pav.).

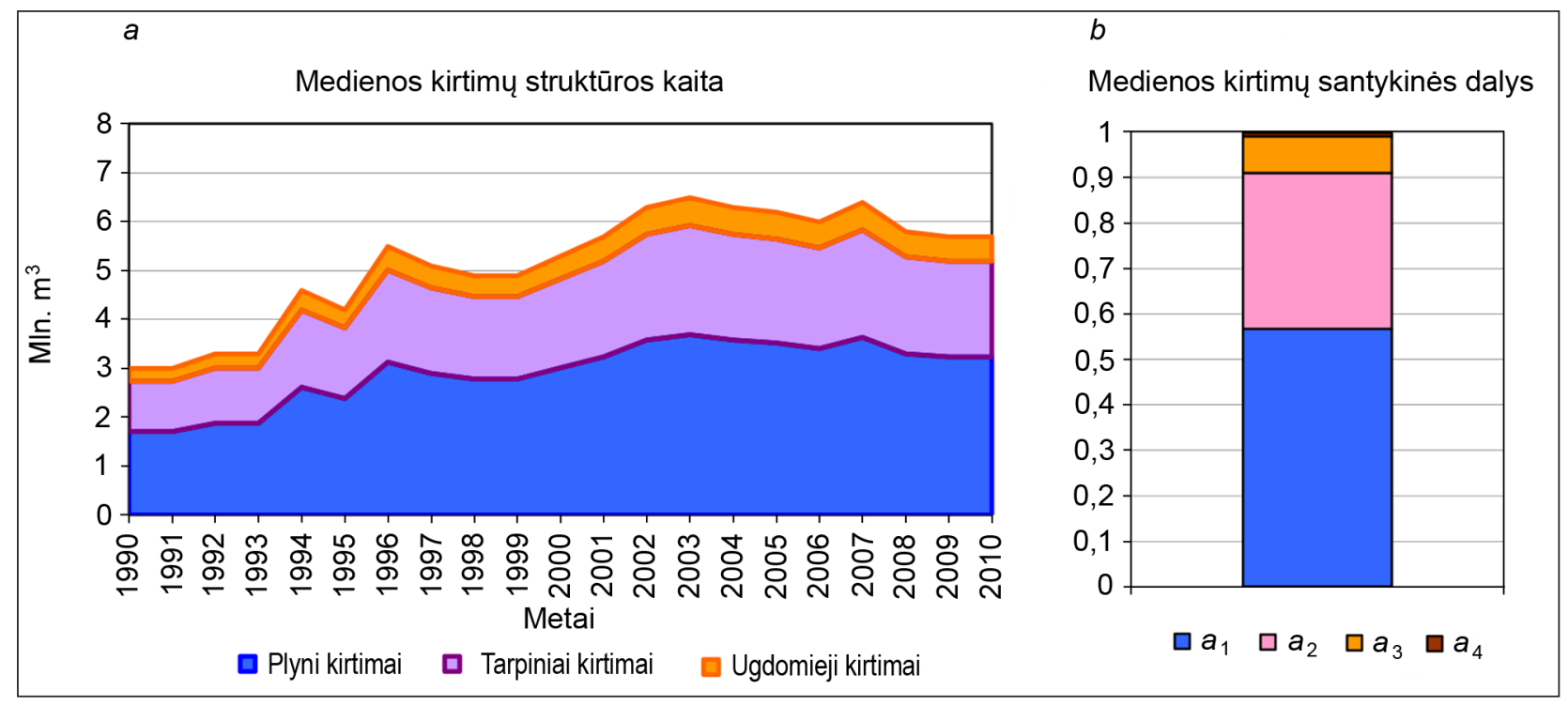

3 pav. a) Likvidinès medienos kirtimų struktūros kaita ir b) medienos kirtimų santykinès dalys pagal (5) lygtị

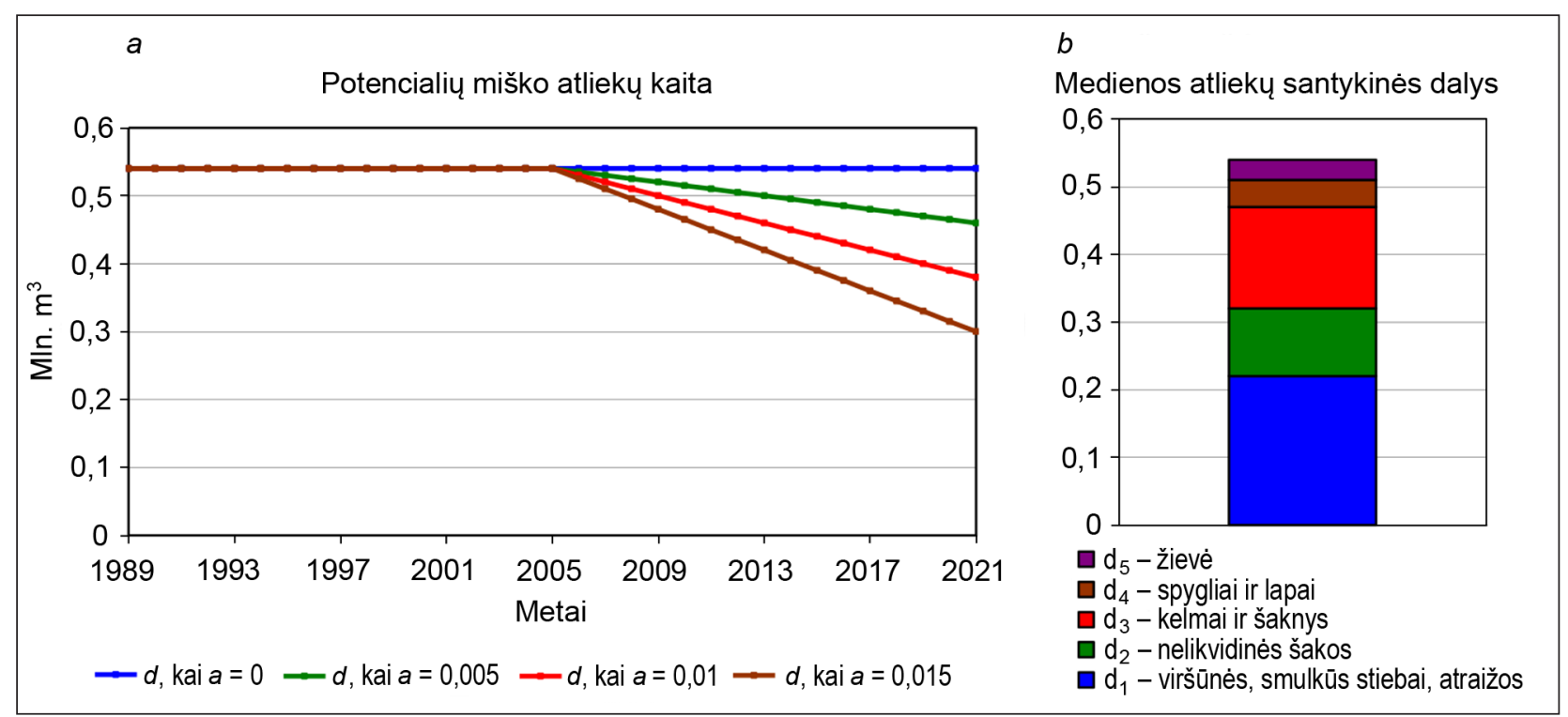

4 pav. Iškertamos biomasės struktūros prognozės didinant skiedros gamybą paliekamų miške atliekų sąskaita: $d$, kai $a=0 ; 0,005 ; 0,01$ ir 0,015 


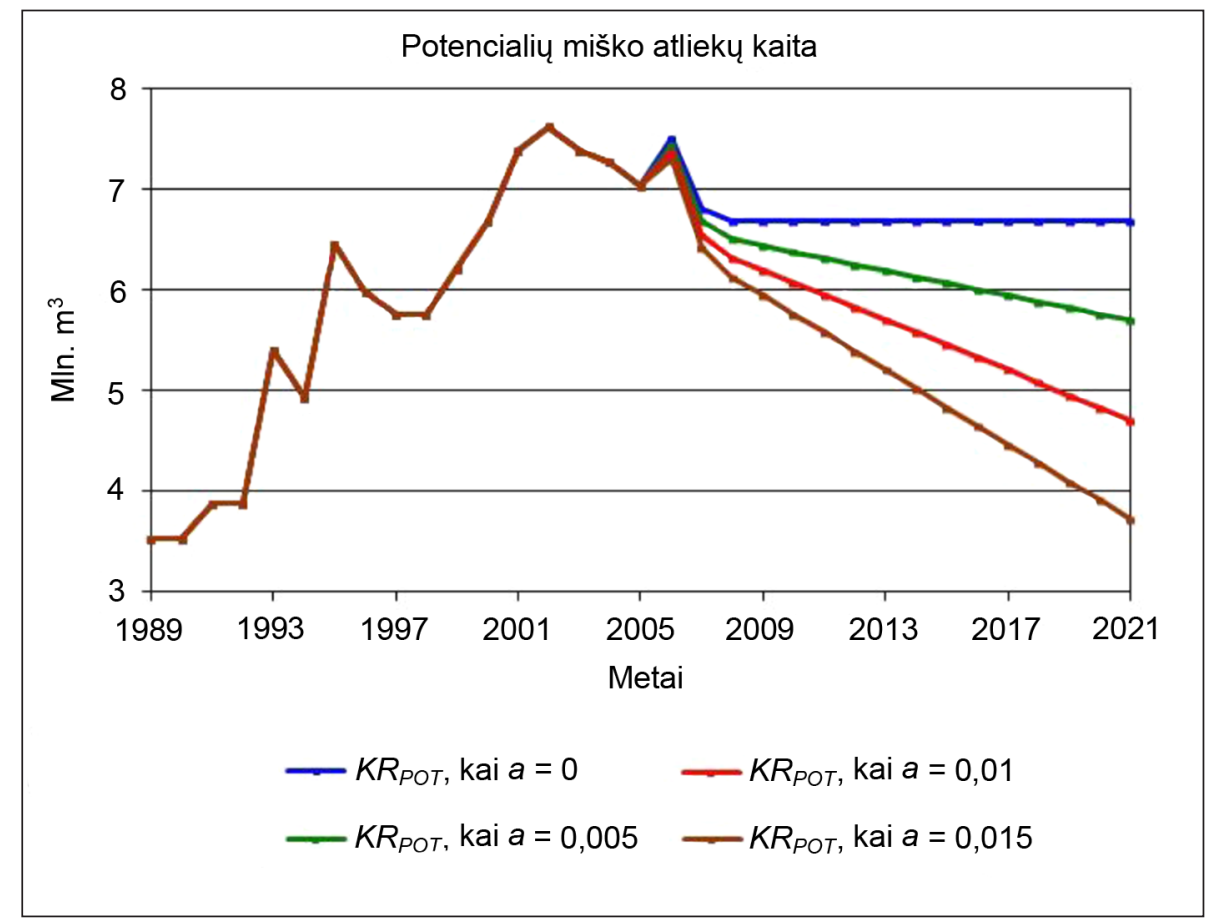

5 pav. Potencialių (nepanaudojamu) miško atliekų kaita: $K R_{\text {Por' }}$ kai $a=0 ; 0,005 ; 0,01$ ir 0,015

Toks matematinis modelis leidžia apžvelgti ne tik mišku kirtimo veiklos retrospektyvą, bet ir galimą perspektyvą ir santykiniais, ir absoliutiniais dydžiais (5 pav.). Miško kirtimu atliekos net esant didžiausioms a reikšmėms sumažètu tik pusiau ir dar siektų apie $3 \mathrm{mln}$. t/metus. Kaip matyti, net esant $a=0,01, \mathrm{t}$. y. panaudojant vidutiniškai $10 \%$ atliekų, kas daugelio miškininkų nuomone $[10,26]$ nekenkia darniam miškų tvarkymui tiek bioịvairovès, tiek miško ištekliu naudojimo efektyvumo požiūriu, iš potencialiu atlieku skiedros gamybą būtu galima padidinti $1 \mathrm{mln} . \mathrm{m}^{3} /$ metus ir pagaminti dvigubai daugiau medienos skiedros nei gaminama dabar.

Miškų ūkio statistikoje, kurią kasmet atnaujina Valstybinè mišku tarnyba, galima rasti išsamius fizinius duomenis apie visus Lietuvos miškus - plotus, rūšinę sudètị, tūrị, produktyvumą ir t. t. Tačiau duomenys apie ūkinę veiklą - kirtimų apimtis, ịvairių sortimentų gamybą ir pardavimus - yra pateikiami tik valstybinių ir restitucijai rezervuotų miškų. Privačių miškų, kuriuose ūkinė veikla yra gana aktyvi, praktiškai pateikiami tik pagrindiniai fizikiniai duomenys, o išsamios informacijos apie kirtimų apimtis nèra.

Remiantis apibendrintais ịvairių šaltinių duomenimis, beveik $30 \%$ stačio miško tūrio gali būti laikoma kirtimo atliekomis. Kirtimo atliekos yra susijusios su kirtimų apimtimis, kurios pastaruosius 10 metų mažai keitessi ir buvo 5,5-6,5 mln. $\mathrm{m}^{3} /$ metus.

Dar vienas miškų išteklių statistikos ypatumas, šiek tiek koreguojantis savivaldybių biokuro potencialo įvertinimą, kad duomenys yra pateikiami pagal uredijas, kurių teritorijos neatitinka savivaldybių teritorijų ribų. Tokių duomenų apdorojimas reikalauja sudètingesnio perskaičiavimo norint nustatyti savivaldybės teritorijoje esantị miško biomasès potencialą, nors biokuro naudojimas nebūtinai turi būti siejamas tik su konkrečioje savivaldybèje esančiais ištekliais.

Taigi, prièmę prielaidą, kad biokurą sudaro miško kirtimo atliekos, malkinè mediena, o nesant kitos paklausos arba esant tinkamai kainai kurui galima panaudoti ir popiermalkes bei plokščiu gamybai tinkamą medieną, taip pat prièmus įvairių ekspertų pateiktas bendras (valstybinių ir privačių miškų) kirtimo apimtis, modelio pagalba atlikti tyrimai ịvertina, kad biokurui pastaraisiais metais, kai kirtimų kiekiai stabilizavosi, kurui būtų galima panaudoti: apie 780 tūkst. $\mathrm{m}^{3} /$ metus kirtimo atliekų, 1660 tūkst. m³/ metus malkinès medienos, 1230 tūkst. $\mathrm{m}^{3} /$ metus popiermalkių ir 600 tūkst. $\mathrm{m}^{3} /$ metus plokščiu medienos. Iš viso tai sudarytų apie 4250 tūkst. m³/metus biokuro, nors konkrečiose savivaldybėse šiu išteklių apimtys gali labai skirtis (4 lentelè).

Kapotinès skiedros gamybos miškuose ilgalaikių ribinių sąnaudų tyrimas

Biokuro gamybą derètų priskirti prie energijos išteklių gavybos ir traktuoti kaip savarankišką veiklą, panašiai kaip durpių kuro ar žalios naftos gavybą.

Skiedros, kaip energetinio kuro gamyba, susideda bent iš trijų technologinių etapų:

1) žaliavos skiedros gamybai paruošimas;

2) skiedros gamyba;

3) skiedros transportavimas vartotojams. 
4 lentelè. Potencialūs medienos biomasès ištekliai savivaldybėse pagal perspektyvumą biokuro gamybai tūkst. $\mathrm{m}^{3} / \mathrm{metus}$

\begin{tabular}{|c|c|c|c|c|c|}
\hline Savivaldybè & Kirtimo atliekos & Malkinè mediena & Popiermalkès & Plokščių mediena & Iš viso \\
\hline Alytaus m. sav. & 0,4 & 1,0 & 0,2 & 0,4 & 2,0 \\
\hline Alytaus r. sav. & 10,2 & 26,9 & 7,2 & 12,2 & 56,5 \\
\hline Druskininku sav. & 4,2 & 7,5 & 13,3 & 6,2 & 31,2 \\
\hline Lazdijų r. sav. & 8,6 & 14,5 & 19,1 & 14 & 56,2 \\
\hline Varènos r. sav. & 26,1 & 51,9 & 71,7 & 15,3 & 165,0 \\
\hline Birštono sav. & 2,5 & 4,8 & 2,7 & 2,9 & 12,9 \\
\hline Jonavos r. sav. & 16,9 & 23,2 & 30,1 & 23,4 & 93,6 \\
\hline Kaišiadorių r. sav. & 11,5 & 29,6 & 18,6 & 13 & 72,7 \\
\hline Kauno m. sav. & 0,3 & 0,8 & 0,2 & 0,2 & 1,5 \\
\hline Kauno r. sav. & 22,7 & 51,0 & 22,9 & 15,8 & 112,4 \\
\hline Kèdainių r. sav. & 22,0 & 90,4 & 14,1 & 29,7 & 156,2 \\
\hline Prienų r. sav. & 12,4 & 23,3 & 13,5 & 14 & 63,2 \\
\hline Raseinių r. sav. & 15,9 & 58,2 & 15,9 & 1,3 & 91,3 \\
\hline Klaipèdos m. sav. & 0,4 & 0,7 & 1,0 & 0,3 & 2,4 \\
\hline Klaipèdos r. sav. & 11,8 & 22,8 & 25,3 & 6,9 & 66,8 \\
\hline Kretingos r. sav. & 10,7 & 16,4 & 24,3 & 7 & 58,4 \\
\hline Neringos sav. & 0,0 & 0,0 & 0,0 & 0 & 0,0 \\
\hline Palangos m. sav. & 0,9 & 1,4 & 2,1 & 0,6 & 5,0 \\
\hline Skuodo r. sav. & 5,7 & 9,0 & 13,0 & 3,6 & 31,3 \\
\hline Šilutės r. sav. & 13,0 & 23,9 & 17,6 & 7,4 & 61,9 \\
\hline Kalvarijos sav. & 2,4 & 5,9 & 1,8 & 4 & 14,1 \\
\hline Kazlų Rūdos sav. & 16,5 & 17,9 & 23,5 & 12,4 & 70,3 \\
\hline Marijampolės sav. & 5,6 & 13,6 & 4,2 & 9,1 & 32,5 \\
\hline Šakių r. sav. & 16,8 & 43,1 & 21,2 & 1,8 & 82,9 \\
\hline Vilkaviškio r. sav. & 6,3 & 15,4 & 4,6 & 10,3 & 36,6 \\
\hline Biržu r. sav. & 20,9 & 23,8 & 35,7 & 10,9 & 91,3 \\
\hline Kupiškio r. sav. & 22,8 & 41,3 & 26,3 & 0,3 & 90,7 \\
\hline Panevéžio m. sav. & 0,2 & 0,3 & 0,2 & 0,2 & 0,9 \\
\hline Panevėžio r. sav. & 38,1 & 67,8 & 45,2 & 36,8 & 187,9 \\
\hline Pasvalio r. sav. & 11,5 & 14,9 & 18,1 & 6,7 & 51,2 \\
\hline Rokiškio r. sav. & 22,1 & 43,8 & 23,0 & 3,8 & 92,7 \\
\hline Akmenès r. sav. & 11,3 & 22,7 & 24,1 & 0,7 & 58,8 \\
\hline Joniškio r. sav. & 11,9 & 30,5 & 14,1 & 17,2 & 73,7 \\
\hline Kelmès r. sav. & 17,4 & 33,5 & 27,1 & 14,4 & 92,4 \\
\hline Pakruojo r. sav. & 14,4 & 32,7 & 10,7 & 14,2 & 72,0 \\
\hline Radviliškio r. sav. & 18,4 & 33,3 & 18,3 & 25,1 & 95,1 \\
\hline Šiaulių m. sav. & 0,0 & 0,0 & 0,0 & 0 & 0,0 \\
\hline Šiaulių r. sav. & 28,4 & 36,9 & 51,9 & 48,3 & 165,5 \\
\hline Jurbarko r. sav. & 26,0 & 36,5 & 39,6 & 9,1 & 111,2 \\
\hline Pagėgių sav. & 3,3 & 4,9 & 4,7 & 1,7 & 14,6 \\
\hline Šilalès r. sav. & 14,0 & 35,6 & 31,0 & 6,3 & 86,9 \\
\hline Tauragès r. sav. & 18,9 & 47,9 & 35,3 & 6,9 & 109,0 \\
\hline Mažeikių r. sav. & 16,3 & 32,9 & 34,9 & 0,9 & 85,0 \\
\hline Plungès r. sav. & 10,5 & 23,7 & 22,9 & 4,6 & 61,7 \\
\hline Rietavo sav. & 11,9 & 30,2 & 28,3 & 5,8 & 76,2 \\
\hline Telšiu r. sav. & 13,8 & 28,6 & 28,8 & 8 & 79,2 \\
\hline Anykščių r. sav. & 20,1 & 60,3 & 39,4 & 1,7 & 121,5 \\
\hline Ignalinos r. sav. & 9,6 & 39,4 & 19,7 & 9,8 & 78,5 \\
\hline Molètų r. sav. & 11,8 & 61,9 & 18,1 & 4,2 & 96,0 \\
\hline Utenos r. sav. & 10,8 & 59,6 & 16,5 & 3,7 & 90,6 \\
\hline Visagino sav. & 0,6 & 2,3 & 1,2 & 0,6 & 4,7 \\
\hline Zarasų r. sav. & 18,1 & 24,9 & 10,3 & 0,9 & 54,2 \\
\hline Elektrènu sav. & 5,6 & 14,3 & 8,4 & 6,9 & 35,2 \\
\hline Šalčininku r. sav. & 20,8 & 23,0 & 39,8 & 24,1 & 107,7 \\
\hline Širvintu r. sav. & 12,4 & 31,5 & 23,4 & 12,7 & 80,0 \\
\hline Švenčionių r. sav. & 27,4 & 33,5 & 49,5 & 15,5 & 125,9 \\
\hline Trakų r. sav. & 17,3 & 43,8 & 22,2 & 25,2 & 108,5 \\
\hline Ukmergès r. sav. & 18,5 & 46,9 & 34,9 & 19 & 119,3 \\
\hline Vilniaus m. sav. & 2,5 & 3,7 & 4,8 & 2,2 & 13,2 \\
\hline Vilniaus r. sav. & 26,4 & 40,2 & 51,0 & 24,2 & 141,8 \\
\hline Iš viso Lietuvoje & 777,6 & 1660,1 & 1227,0 & 584,4 & 4249,1 \\
\hline
\end{tabular}


Kiekviename šių etapų naudojamos skirtingos technologijos, sąlygojančios būdingas savitąsias sąnaudas. Skiedros išteklių rinkos kainos turètų būti grindžiamos ilgalaikèmis ribinèmis gamybos sąnaudomis.

Žaliavos skiedros gamybai paruošimas. Tai sudètingiausias ir daugiausia problemų keliantis biokuro ruošos etapas. Skiedros gamybai gali būti naudojama tam tikra iš miško kirtimų ištraukiamos medienos dalis, kuri neturi paklausos kaip padarinė mediena. Šiuo atveju ištraukimo sąnaudos paprastai yra įskaičiuojamos ị padarinès medienos savikainą. Kadangi šiame tyrime keliamas uždavinys ištirti skiedros gamybos padidinimo galimybes iš miške tradiciškai paliekamų biomasès atliekų vykdant pagrindinius ir tarpinius kirtimus. Čia analizuojamas bendriausias žaliavos paruošimo variantas, apimantis medienos iškirtimą, jos surinkimą bei ištraukimą iki aikštelių, skirtų skiedros gamybai, būdingas ugdomuosiuose kirtimuose.

Tokios veiklos ilgalaikių ribinių sąnaudų (IRK) analizei reikia žinoti naudojamo technologinio proceso bei kapitalo sąnaudas. Atlikti tyrimai rodo, kad medienos atliekų (žabų) savikaina (ZRK) skiedros gamybos aikšteleje labiausiai priklauso nuo miško ploto vienete susidarančiu atliekų kiekio (tankio) $(A T)$ ir vidutinio atstumo iki smulkinimo aikštelès (ISA). Miškininkų tyrimų rezultatus, pasitelkus jų naudojamus atliekų ištraukimo iš miško atstumus [21], pakankamu tikslumu galima aprašyti tiesine lygtimi:

$$
Z R K=60,18-0,0545 \cdot A T+0,0218 \text { * ISA; }
$$

čia $A T$ - 1 ha plote susidarančių atliekų tūris $\mathrm{m}^{3}$;
ISA - vidutinis atstumas iki smulkinimo aikštelès m.

Šios lygties pagrindu gauti rezultatai, palyginti su miško kirtimo atliekų žaliavos rinkos kaina $(R K)$, pateikti 6 pav., rodo, kad biokuro žaliavos ištraukimas esant mažesniam kaip $10 \mathrm{~m}^{3} /$ ha atliekų tankiui ekonomiškai nėra naudingas.

Kirtimo atliekų ištraukimas yra nuostolingas, kai ju savikaina viršija dabartinę rinkos kainą. Savivaldybės turètų disponuoti informacija apie jų teritorijoje esamų miško atliekų susidarymo vietas ir jų charakteristikas, kad galètų taikyti priemones, skatinančias geresni jų panaudojimą.

Skiedros gamyba. Skiedros gamybos IRK analizei naudoti miškininkų paskelbti duomenys. Skaičiavimai atlikti 20 tūkst. $\mathrm{m}^{3} /$ metus kapotinès skiedros gamybos vienetui (imonei). Tokios immonès pagrindiniai techniniai ir ekonominiai rodikliai buvo išsamiai analizuoti Švedijos nacionalinès miškų ūkio valdybos bei Miškų ir saugomų teritorijų departamento prie LR Aplinkos ministerijos dvišaliame projekte „Medienos panaudojimo kurui plètra Lietuvoje“ [25].

Čia apsiribojama skiedros gamybos $I R K$ analize, remiantis minètame projekte pateiktais sprendimais. Tokiai imonei reikalingos įrangos kapitalo sąnaudu skaičiavimas žaliavos ištraukimo ir jos smulkinimo operacijoms pateiktas 5 lentelèje, o eksploatacijos sąnaudos - 6 lentelèje.

Skaičiavimai parodè, kad galimi rezervai biokuro sąnaudu mažinimui slypi atliekų ištraukimo iš miškų operacijoje (7 pav.).

Sąlyginai pastovias eksploatacijos sąnaudas sudaro darbuotoju atlyginimas ir socialinio draudimo mokestis

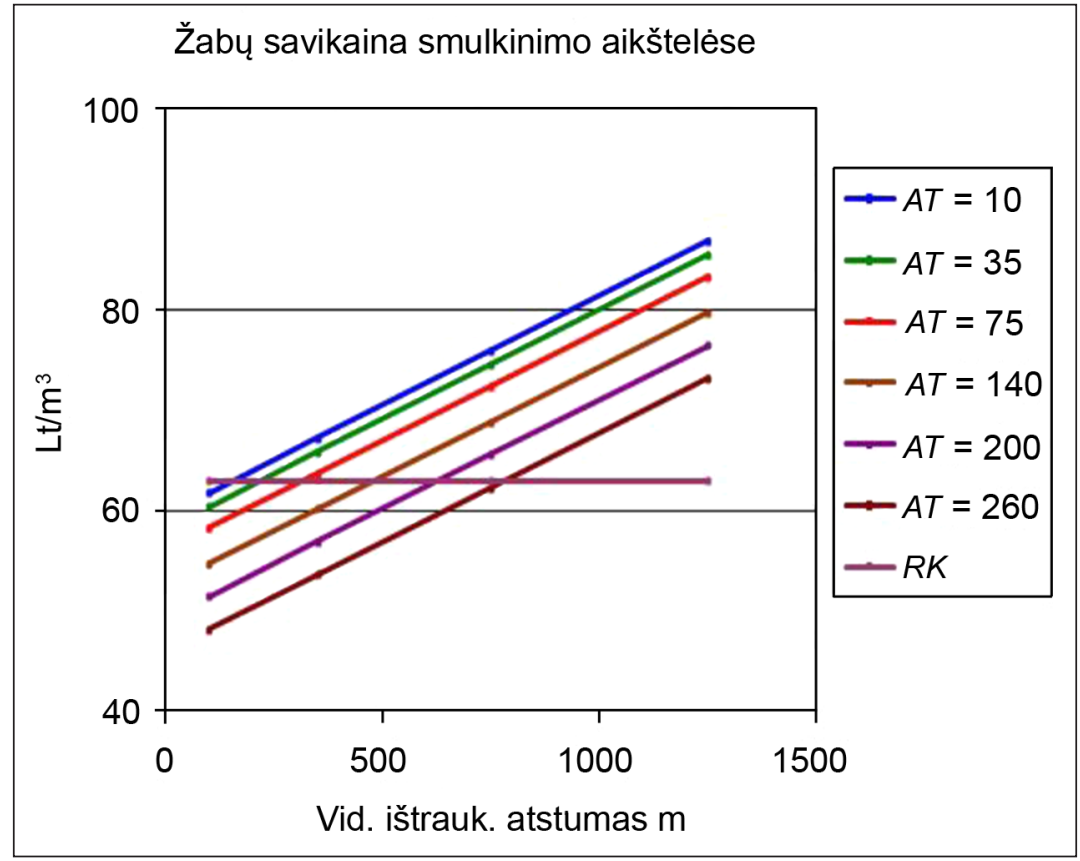

6 pav. Žaliavos ruošos sąnaudų atliekų tankio ploto vienete $A T\left[\mathrm{~m}^{3} / \mathrm{ha}\right.$ ir vidutinio ištraukimo atstumo ISA [m] priklausomumas. $R K$ - dabartinè žaliavos rinkos kaina smulkinimo aikštelèje 
5 Ientelè. Kapitalo sąnaudos skiedros gamybai jaunuolynų ugdymo kirtimuose

\begin{tabular}{|c|c|c|c|c|c|c|c|c|c|c|c|}
\hline \multirow[b]{2}{*}{ Nr. } & \multirow[b]{2}{*}{$\begin{array}{l}\text { Kapitalo sąnaudos } \\
\text { žaliavos ištraukimui } \\
\text { ir smulkinimui } \\
\text { jaunuolynų } \\
\text { ugdymo } \\
\text { kirtimuose }\end{array}$} & \multicolumn{10}{|c|}{ Sąnaudų sandai } \\
\hline & & $\begin{array}{l}\text { Inves- } \\
\text { ticijos 1, } \\
\text { t. Lt }\end{array}$ & $\begin{array}{c}\text { Trukmè } \\
1, \mathrm{~m}\end{array}$ & $\begin{array}{l}\text { Kapitalo } \\
\text { atsta- } \\
\text { tymo } \\
\text { fakto- } \\
\text { rius } 1\end{array}$ & $\begin{array}{c}\text { Kapitalo } \\
\text { kaštai } \\
\text { 1,t.Lt/ } \\
\text { metus }\end{array}$ & $\begin{array}{c}\text { Kapitalo } \\
\text { kaštai } 1 \\
\text { Lt/m³ }\end{array}$ & $\begin{array}{l}\text { Inves- } \\
\text { ticijos 2, } \\
\text { t. Lt }\end{array}$ & $\begin{array}{c}\text { Trukmè } \\
2, m\end{array}$ & $\begin{array}{l}\text { Kapitalo } \\
\text { atsta- } \\
\text { tymo } \\
\text { fakto- } \\
\text { rius } 2\end{array}$ & $\begin{array}{l}\text { Kapitalo } \\
\text { kaštai 2, } \\
\text { t.Lt/metus }\end{array}$ & $\begin{array}{l}\text { Kapitalo } \\
\text { kaštai 2, } \\
\mathrm{Lt} / \mathrm{m}^{3}\end{array}$ \\
\hline 1. & $\begin{array}{l}\text { Kapoklè BRUKS } \\
604 \mathrm{CT}\end{array}$ & 0 & 10 & 0,163 & 0 & & 350 & 10 & 0,163 & 56,96 & \\
\hline 2. & $\begin{array}{l}\text { Traktorius } \\
\mathrm{K}-700\end{array}$ & 0 & 10 & 0,163 & 0 & & 210 & 10 & 0,163 & 34,18 & \\
\hline 3. & $\begin{array}{l}\text { Manipuliatorius } \\
\text { Loglift } \\
\text { F } 20 \text { L }\end{array}$ & 0 & 5 & 0,264 & 0 & & 89 & 5 & 0,264 & 23,48 & \\
\hline 4. & $\begin{array}{l}\text { Traktorius } \\
\text { MTZ-82 } \\
\text { (2 vnt.) }\end{array}$ & 108,5 & 5 & 0,264 & 28,62 & & 0 & 5 & 0,264 & 0 & \\
\hline 5. & $\begin{array}{l}\text { Vilkikas Weimer } \\
\text { WE-8 } \\
\text { (2 vnt.) }\end{array}$ & 266 & 5 & 0,264 & 70,17 & & 0 & 5 & 0,264 & 0 & \\
\hline & $\begin{array}{l}\text { Iš viso kapitalo } \\
\text { sąnaudy }\end{array}$ & 374,5 & & & 98,79 & 4,94 & 649 & & & 114,6 & 5,731 \\
\hline
\end{tabular}

6 lentelè. Eksploatacijos sąnaudos biomasès ištraukimui ir smulkinimui jaunuolynų ugdymo kirtimuose

\begin{tabular}{|c|c|c|c|c|c|c|c|}
\hline \multirow{3}{*}{ Nr. } & \multirow{3}{*}{$\begin{array}{l}\text { Eksploatacijos sąnaudos } \\
\text { ištraukimui ir smulkinimui } \\
\text { jaunuolynų ugdymo } \\
\text { kirtimuose }\end{array}$} & \multicolumn{6}{|c|}{ Sąnaudų sandai } \\
\hline & & \multicolumn{3}{|c|}{$\begin{array}{l}\text { Metinès sąnaudos } \\
\text { tūkst. Lt }\end{array}$} & \multicolumn{3}{|c|}{$\begin{array}{c}\text { Santykinès sąnaudos } \\
\mathrm{Lt}^{3} \mathrm{~m}^{3}\end{array}$} \\
\hline & & $\begin{array}{l}\text { Ištraukimo } \\
\text { sąnaudos }\end{array}$ & $\begin{array}{l}\text { Smulkinimo } \\
\text { sąnaudos }\end{array}$ & $\begin{array}{l}\text { Suminess } \\
\text { gamybos } \\
\text { sąnaudos }\end{array}$ & $\begin{array}{l}\text { Ištraukimo } \\
\text { sąnaudos }\end{array}$ & $\begin{array}{l}\text { Smulkinimo } \\
\text { sąnaudos }\end{array}$ & $\begin{array}{l}\text { Suminès } \\
\text { gamybos } \\
\text { sąnaudos }\end{array}$ \\
\hline 1. & $\begin{array}{l}\text { Pastoviosios eksploatacijos } \\
\text { sąnaudos }\end{array}$ & 455,9 & 62,88 & 518,8 & 22,79 & 3,144 & 25,94 \\
\hline 2. & Darbuotoju atlyginimai & 348 & 48 & 396 & 17,4 & 2,4 & 19,8 \\
\hline 3. & Socialinis draudimas & 107,9 & 14,88 & 122,8 & 5,394 & 0,744 & 6,138 \\
\hline 4. & $\begin{array}{l}\text { Kintamosios eksploatacijos } \\
\text { sąnaudos }\end{array}$ & 276 & 84 & 360 & 13,8 & 4,2 & 18 \\
\hline 5. & $\begin{array}{l}\text { Žaliavos mokestis } \\
\text { savininkams }\end{array}$ & 100 & 0 & 100 & 5 & 0 & 5 \\
\hline 6. & Kuras & 160 & 80 & 240 & 8 & 4 & 12 \\
\hline 7. & Remontas ir priežiūra & 16 & 4 & 20 & 0,8 & 0,2 & 1 \\
\hline \multirow[t]{2}{*}{8.} & Iš viso sąnaudų & 830,7 & 261,5 & 1092 & 41,53 & 13,07 & 54,61 \\
\hline & Prielaidos & & & & & & \\
\hline 9. & $\begin{array}{l}\text { Vidutinis ménesio atlyginimas } \\
\text { Lt/mèn. }\end{array}$ & 2000 & 2000 & 2000 & & & \\
\hline 10. & Darbuotojų skaičius & 14,5 & 2 & 16,5 & & & \\
\hline 11. & Dyzelinio kuro kaina Lt/l & 3,5 & 3,5 & 3,5 & 3,5 & 3,5 & 3,5 \\
\hline 12. & $\begin{array}{l}\text { Dyzelinio kuro sąnaudos } \\
\text { tūkst. I }\end{array}$ & 45,71 & 22,86 & 68,57 & 2,286 & 1,143 & 3,429 \\
\hline 13. & Dyzelinio kuro tankis kg/l & 0,9 & 0,9 & 0,9 & 0,9 & 0,9 & 0,9 \\
\hline 14. & $\begin{array}{l}\text { Dyzelinio kuro sąnaudos } \\
\text { svorio vnt. }(\mathrm{t})\end{array}$ & 41,14 & 20,57 & 61,71 & 2,057 & 1,029 & 3,086 \\
\hline 15. & $\begin{array}{l}\text { Dyzelinio kuro sąnaudos } \\
\text { energ. vnt. }\left(\mathrm{kWh} / \mathrm{m}^{3}\right)\end{array}$ & & & & 24,44 & 12,22 & 36,66 \\
\hline 16. & $\begin{array}{l}\text { Dyzelinio kuro indèlis } \\
\mathrm{kWh} / \mathrm{MWh}\end{array}$ & & & & 4,857 & 2,428 & 7,2858 \\
\hline
\end{tabular}




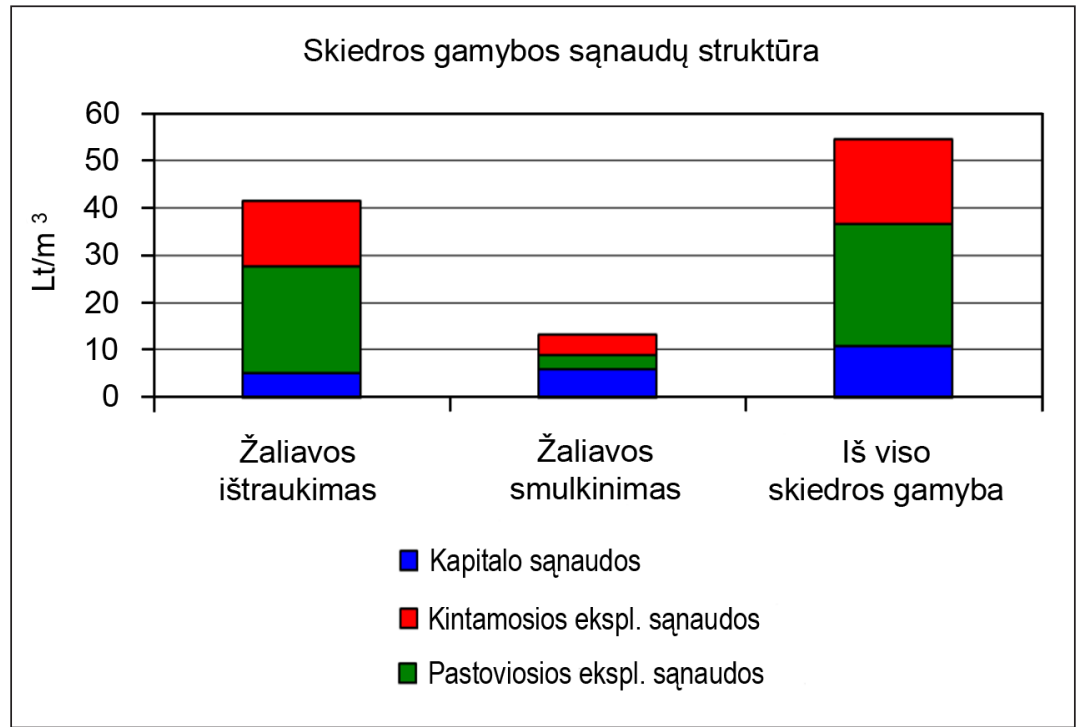

7 pav. Skiedros gamybos sąnaudų struktūra

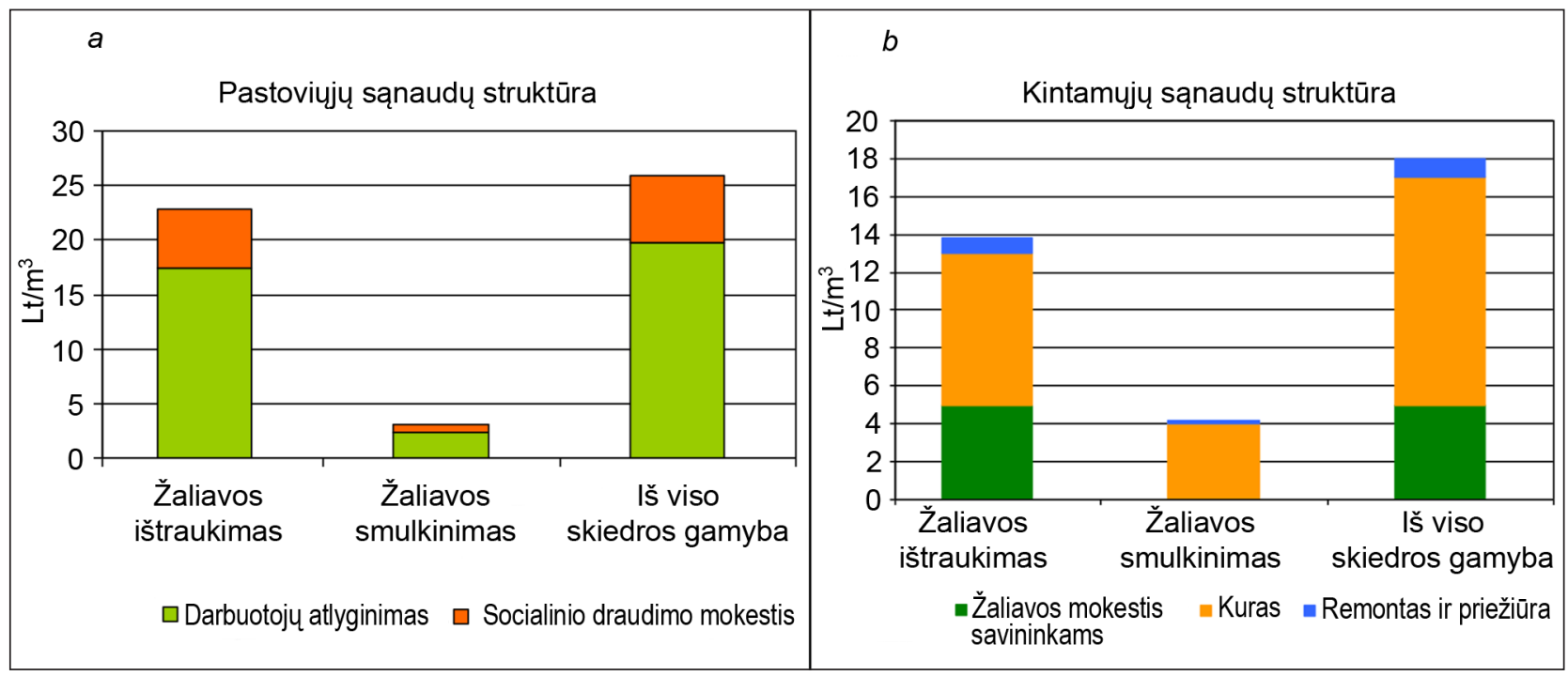

8 pav. a) Pastoviujų sąnaudų struktūra ir b) kintamujų sąnaudų struktūra

(8 pav.). Didžiausios išlaidos susidaro ištraukiant žaliavą. Galima pažymėti, kad šiuos darbus gali dirbti ir žemos kvalifikacijos darbuotojai. Būtent čia galima savivaldybių iniciatyva idarbinant bedarbius ir t. t.

Pagrindinè kintamųų sąnaudų dedamoji yra išlaidos kurui (8 pav.). Žaliavos mokestis galètų paskatinti privačių miškụ savininkus surinkti medienos atliekas. Atkreiptinas dèmesys, kad ištraukiant miško atliekas sunaudojama nemažai dyzelinio kuro. Kintamosios sąnaudos galètų būti sumažintos taikant kurui mokestines lengvatas.

Dyzelinio kuro naudojimo biokuro gamybai efektyvumas nèra didelis ( 9 pav.). Tai tampa svariu veiksniu plečiant medienos kuro ruošą jaunuolynuose, kur mažas atliekų tankis ir didelis jų ištraukimo atstumas. Ši problema galètų būti sprendžiama jau sodinant miškus (numatant kelius įvažiuoti efektyvesnei technikai).
Skiedros transportavimo ị katilines sąnaudas lemia ne tik atstumas nuo skiedros gamybos vietos, bet ir naudojama technika (10 pav.). Šios sąnaudos yra reikšmingos esant didesniam kaip $20 \mathrm{~km}$ atstumui nuo gamybos vietos ir sudaro per $10 \%$ savikainos transportuojant didesniu kaip $40 \mathrm{~km}$ atstumu.

Atkreiptinas dėmesys, kad šias sąnaudas būtų galima sumažinti numatant tarpines skiedros saugojimo aikšteles rajono teritorijoje. Taip būtų pagerintas skiedros pristatymas vartotojams (pagal poreiki).

Reikia pažymèti, kad nustatytos skiedros gamybos sąnaudos $2010 \mathrm{~m}$. kainomis ir sąnaudomis yra mažesnès už dabartinę rinkos kainą. Sąnaudos galètų būti sumažintos geriau planuojant darbus savivaldybių lygiu (pagal Nacionalinę programą) ir panaudojant turimus išteklius. 


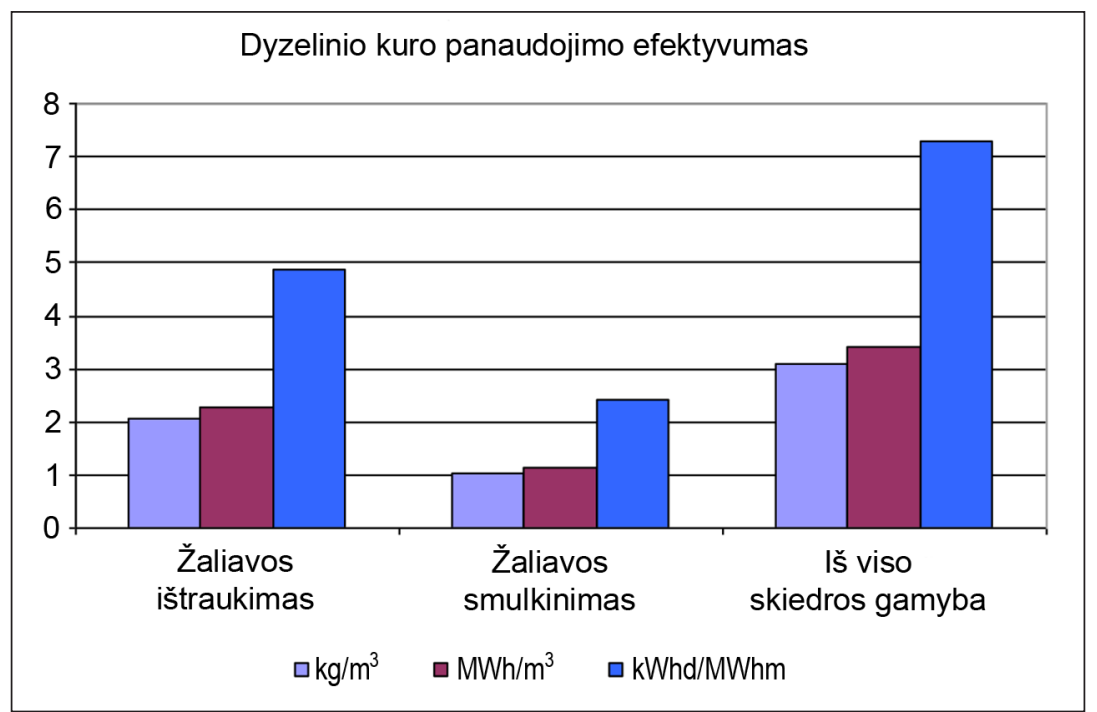

9 pav. Dyzelinio kuro sąnaudų natūriniais ir energijos vienetais palyginimas su medienos kuro verte

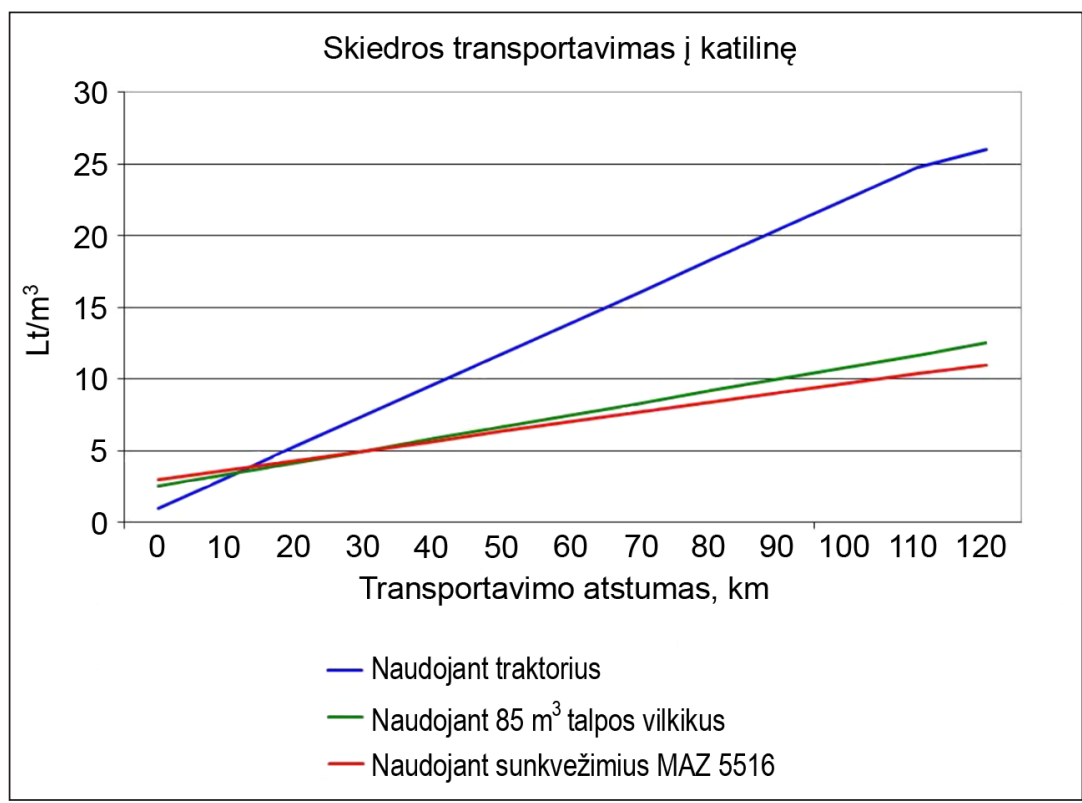

10 pav. Skiedros transportavimo sąnaudos naudojant jivairias transportavimo priemones

\section{IŠVADOS}

Naudojantis apibendrintais miškų tyrimų ekspertų, miškotvarkos technologijų ir miškų statistikos duomenimis, pateiktame tyrime sukurti biokuro gamybos išteklių potencialo aplinkosauginio ir ekonominio vertinimo metodika bei atitinkamas modelis, kurie galètų būti naudojami kaip ịrankis savivaldybių darnaus biokuro energetikos ūkio planavimui, ivvertinantis tiek turimus išteklius savivaldybès teritorijoje, tiek ir biokuro gamybos sąnaudas.

Tyrimas, atliktas naudojantis sukurta metodika ir modeliu, parodè, kad potencialių medienos atliekų panaudojimą padidinus $10 \%$ (tai nekenkia darniam mišku tvarkymui tiek bioịvairovès, tiek miško išteklių naudojimo efektyvumo požiūriu), kapotinès skiedros gamybą būtų galima padidinti $1 \mathrm{mln} . \mathrm{m}^{3} /$ metus ir pagaminti dvigubai daugiau medienos skiedros nei gaminama dabar.

Prièmus prielaidas, kad biokurą sudaro miško kirtimo atliekos, malkinė mediena, o nesant kitos paklausos arba esant tinkamai kainai kurui galima panaudoti ir popiermalkes bei plokščių gamybai tinkamą medieną, tyrimas leido ịvertinti, kad biokurui būtų galima panaudoti apie 780 tūkst. $\mathrm{m}^{3} /$ metus kirtimo atliekų, 1660 tūkst. $\mathrm{m}^{3} /$ metus malkinès medienos, 1230 tūkst. $\mathrm{m}^{3} /$ metus popiermalkių ir 600 tūkst. $\mathrm{m}^{3} /$ metus plokščiu medienos. Iš viso tai sudarytų apie 4250 tūkst. $\mathrm{m}^{3}$ biokuro per metus.

Atliekant ekonominio vertinimo tyrimus nustatyta, kad svarbiausi veiksniai, lemiantys biomasès panaudo- 
jimą biokuro gamybai, yra biomasès ištraukimo iš miškų atstumas, 1 ha plote susidarančių atliekų tūris ir transportavimo it katilines atstumas. Biokuro gamybos grandinejje biomasès ištraukimo iš miškų operacijos sąnaudos sudaro apie $70 \%$ medienos skiedrų gamybos sąnaudų. Biokuro transportavimo į katilines sąnaudos atsižvelgiant i naudojamos technikos našumą ir kuro vartojimą padidina sąnaudas $>10 \%$ (transportuojant daugiau kaip $40 \mathrm{~km}$ atstumu).

Gauta 20130515

Priimta 20130705

\section{Literatūra}

1. Lietuvos Respublikos atsinaujinančiu ištekliu energetikos istatymas. 2011 m. gegužès 12 d. Nr. XI-1375.

2. Country Report: Lithuania. The European Renewable Energy Study. Kaunas: LEI, 1994.

3. Review of Lithuania's Own Energy Resources and the Scope for Utilizing them for Energy Purposes. EK PHARE projekto ataskaita. Lahmeyer International and Cowi Consult. Vilnius, 1994.

4. Lietuvos vietiniai energijos ištekliai. PHARE projekto galutine ataskaita. Cowi-Allplan-Etna, 1997.

5. Atsinaujinančiujų ir vietinių energijos išteklių naudojimo didinimas Lietuvoje. Baigiamoji ataskaita. Danish Energy Management A/S, Environmental Related Energy Sector Programme - Lithuania, 2003 m. gruodis.

6. Renewable Energy Policy Review: Lithuania. EC Altener Programme. LEI - EREC, May 2004.

7. Miško kuro ruošos integravimas ì mišku ūkị. Miškininkystès, technologiju ir miško kuro ruošos ekonominiu tyrimu Lietuvoje rezultatai. Lietuvos-Švedijos projekto ataskaita. Vilnius: Lutute, 2003.

8. Lietuvos mišku ūkio statistika 2012. Valstybinė miškotvarkos tarnyba. Kaunas, 2013.

9. Nacionalinés biomasès ir biokuro gamybos ir naudojimo technologiju platformos galimybiu studija. Vilnius, 2006.

10. Tebèra A. Medienos naudotinos kurui ištekliai ir ju apskaita. INTERREG III B projekto BBN seminaro pranešimas. LŽŪU, 2005-11-24.

11. Medynu kirtimo atliekų apskaičiavimo modelis. Ataskaita (vad. A. Tebera). Girionys: KMAIK, 2007. 38 p.

12. Lietuvos atsinaujinančiu energijos ištekliu naudojimo skatinimo veiksmu planas 2010-2020 m. Galutinè ataskaita. Lietuvos biomasès energetikos asociacija LITBIOMA. Vilnius, 2008.

13. Saladis J., Armolaitis K., Gedminas A. Miško kirtimu atlieku ištekliu ir ju paèmimo iš miško ekologinès rizikos jvertinimas ir rekomendaciju parengimas. Moksliniotiriamojo darbo ataskaita. Lietuvos nepriklausomų medienos matuotojų asociacija. Akademija, 2008.
14. Nacionalines biomases ir biokuro gamybos ir naudojimo technologiju platformos strateginiu tyrimu planas, 2007. 57 p.

15. Kuliešis A. Lietuvos miškų ištekliai ir naudojimo perspektyvos. Medienos atlieku perdirbimas ir panaudojimas kurui. Vilnius, 1999. P. 11-20.

16. Lietuvos atsinaujinančiu energijos ištekliu naudojimo skatinimo veiksmu planas 2010-2010 m. Taikomojo mokslinio tyrimo ataskaita. Vilnius: Lietuvos biomasès energetikos asociacija LITBIOMA, 2008. 215 p.

17. Mizaraitè D., Mizaras S., Sadauskienè L. Medienos kuro sunaudojimo kaimo vietovese tyrimas. Baigiamoji ataskaita, 2009.

18. Gedminas A., Ozolinčius R. Kaip ir kokie miškai auginami malkoms, arba energetinè miškininkystè. Inovatyvūs mokymo(si) metodai ir naujausios technologijos gamtos moksly bakalauru rengimui. Lietuvos miškų institutas, 2007. http://gamta.vdu.lt/bakalaurai/ pop_straipsniai/miskai_malkoms/miskai_malkoms. html

19. Lietuvos energetika 2011. Energetikos statistikos leidinys. ISSN 1822-5268. Lietuvos energetikos institutas, 2012.

20. FAO Global Forest Resources Assessment 2005. Lithuania: Country Report.

21. Sadauskienė L., Mizaras S., Mizaraitė D., Aleinikovas M. Medienos kuras: ištekliai, ruošos sąnaudos ir naudojimo katilinèse efektyvumas. Miškininkystè. 2009. Nr. 2(66).

22. Kenstavičius J. Mišku resursai, ju paruošos, poreikiai ir būklès gerinimo problemos. Kaunas, 1989. 89 p.

23. Medienos atlieku ištekliai ir ju panaudojimo galimybès. (Darbo vad. J. Grigaliūnas). Lietuvos miškų instituto ataskaita. Girionys, 1996. 38 p.

24. Rutkauskas A. Lietuvos miškai bei miško kirtimo atlieku ištekliai kuro ruošai. Pranešimas konferencijoje „Biokuras kaip energijos šaltinis Baltijos regione“. Vilnius, 2005.

25. Baltrušaitis A., Anderson L. Biokuro panaudojimo Lietuvoje galimybès. Lietuvos-Švedijos bendro projekto galutine ataskaita. Vilnius, 2000. $132 \mathrm{p}$.

26. Lynikas M., Palicinas M., Tebèra A., Mozgeris G., Radzevičiūtė A., Vrubliauskas S., Dzenajavičienė E. F. Modeling the amount of cutting residues and timber volumes suitable for fuel. Proceedings of the Third International Scientific Conference "Rural Development 2008”, Lithuanian University of Agriculture, Volume 3, Book 2. P. 294-301. 
Eugenija Farida Dzenajavičienė, Vaclovas Kveselis,

Matas Tamonis

\section{MODELLING OF THE POTENTIAL AND PRODUCTION FOR FOREST BIOMASS RESOURCES}

\section{Summary}

Energy generation using renewable energy sources is one of the most significant priorities in the energy policy of the European Union. EU attempts to mitigate negative impact on environment from the energy sector by reduction of $\mathrm{CO}_{2}$ emissions as well as reduce economic dependence on fuel import from third-party countries. Biomass fuel is one of renewable energy sources the use of which stimulates development of local economics and creates new jobs. Besides, the use of RES forms possibilities to ensure security of energy supply via diversification of energy sources.

There are still no reliable tools - methods and models - for assessment of RES potential and planning investments on the basis of marginal biomass fuel production costs as well as for planning investments in the heat supply sector based on the principles of sustainable energy planning and implementing modern technologies in autonomous and district heating sectors.

In the presented study a method and a respective model was developed for the assessment of biomass production potential. Modelling showed that extraction up to $10 \%$ of potential wood waste could increase wood biomass production by 1 million $\mathrm{m}^{3} /$ year and double the production of wood chips. The article shows that the total solid biomass potential could be appr. 4250 thousand $\mathrm{m}^{3} /$ year. Biomass fuel production potential assessment methodology linking potential biomass resources available for biofuel production in the area of a specific municipality with forest felling and management volumes as well as investigations of biofuel production and transportation costs show that biomass density / 1 ha of forest area, extraction and biofuel transportation distance to the boiler-houses are the main factors influencing the use of biofuel.

Key words: biomass, modelling, planning, production costs
Эугения Фарида Дзенаявичене, Вацловас Квеселис, Матас Тамонис

\section{МОДЕЛИРОВАНИЕ ПОТЕНЦИАЛА И ПРОИЗВОДСТВА ЛЕСНОГО БИОТОПЛИВА}

Резюме

Производство энергии, из обновляющихся источников один из приоритетов энергетической политики Евросоюза (ЕС). ЕС стремится снизить экономическую зависимость от импортируемого топлива из третьих стран, а также отрицательное воздействие энергетики на окружающую среду за счет сокращения выбросов $\mathrm{CO}_{2}$. Биотопливо - один из возобновляемых источников энергии, использование которого стимулирует экономический рост и создает рабочие места. Кроме того, использование местного топлива повышает надежность энергоснабжения.

До сих пор не разработаны надежные инструменты методики и модели - для оценки потенциала и планирования инвестиций для освоения возобновляемых источников на основе издержек производства биотоплива, а также планирования инвестиций в секторе теплоснабжения основанного на принципах гармоничного планирования и используя современные технологии для индивидуального и централизованного теплоснабжения.

В этой работе представлена методология оценки потенциала биомассы для производства биотоплива и соответствующая численная модель. Моделирование показало, что при увеличении доли использования потенциальных отходов на 10 \%, производство древесной щепы может быть увеличено на 1 милл. м в год, т. е. создает возможность производить в два раза больше щепы, чем производится сейчас. Показано,

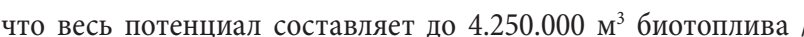
год. Методика оценки потенциала биотоплива, связывающая потенциальные ресурсы биомассы на конкретной территории с объемом лесозаготовок и лесопользования, и исследование производственных и транспортных расходов биотоплива показали, что наиболее важными факторами в использовании лесной биомассы являются расстояние вытаскивания отходов из леса, плотность отходов на 1 га, а также потребление транспортного топлива, зависимо от расстояния транспортировки биотоплива в котельню.

Ключевые слова: биотопливо, моделирование, планирование, расходы производства 